\title{
أحرف الواو الوصل و معانيها في الجزء الثلاثين
}

\section{Suharia Sarif, Srinurninagsih Ismail, Cutri A. Tjulau}

Sastra Arab, Fakultas Ilmu Budaya - UMG

$$
\text { تجريد البحث }
$$

هذا البحث يتكلم عن " أحرف الواو الوصل و معانيها في الجزء الثلاثين". وهذا البحث

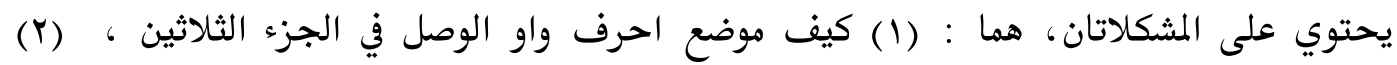
كيف احرف واو الوصل و معانيها في الجزء الثلاثين. في هذه البحث استحدم الباحث بحثنا نوفئ نوعيا

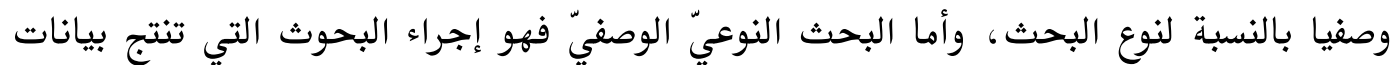

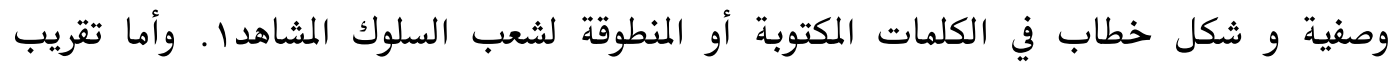
البحث استخدم الكاتب طريقة تحليلية نحوية. وهذا التقريب يسعى إلى أكثر التحليل الوثيق في

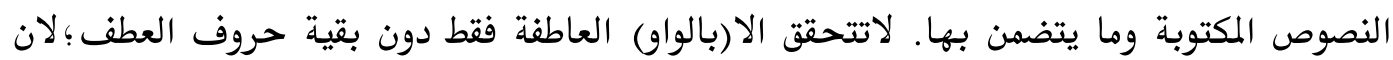

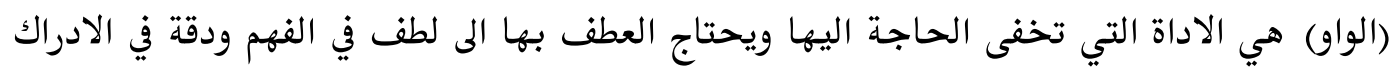
اذ لاتفيد الامجرد الربط وتشريك ما بعدها لما قبلها في الحكم نحو (مضى وقت الت الكسل الكسل وجاء زمن العمل,وقم واسع في الخير) بخلاف العطف بغير الواو فيفيد مع التشريك معاني اخرى كالترتيب

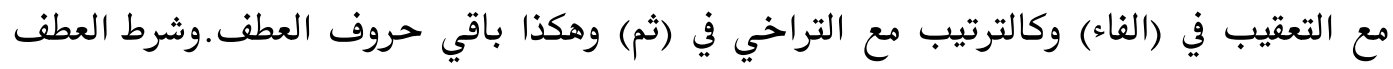

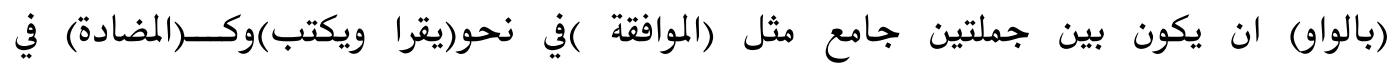

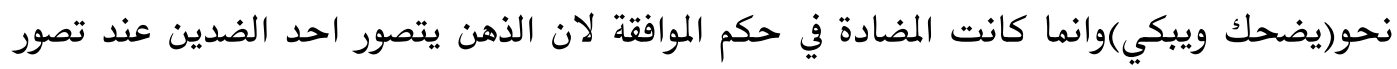
الآخر ف(العلم)يخطر على البال عند ذكر (الجهل)كما تخطر الكتابة عند ذكر (القراءة),(والجامع)

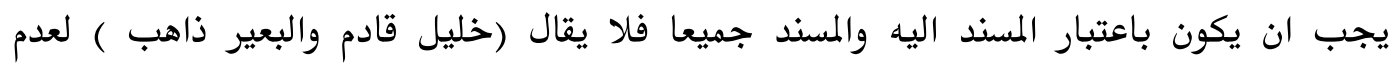
الجامع بين المسند اليهما.

الكلمات الرئيسية: أحرف الواو، الوصل، معاني، الجزء الثلاثين

ا ليكسي موليونج، طرق البحث النوعيّ، (باندنج : رامج روصدا كاريا،...r)، ص.r

\section{'A Jamiy, Jurnal Bahasa dan Sastra Arab} Volume 06, No. 2, September 2017 
لقد اتخذ الإسلام من العربية لسانا منذ أن نزل القرآن. فانتشرت اللغة العربية بانتشار الإسلام دقيقة فدقيقة. واعلم الغة القرآن، هو كلام الله القديم الذي أنزله إلى رسوله محمد صلى الله عليه وسلم - بوسيلة جبريل - عليه السلام - باللفظ والمعنى للمتعبد بتلاوته وإعجاز

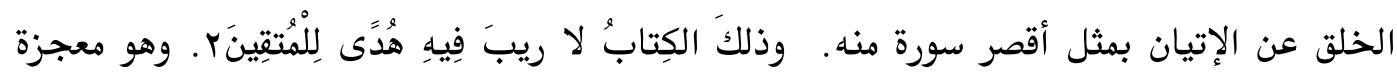
خالدة التي لا يزيدها التقدم العلمي إلا رسوخا في الإعجاز، كما قاله مناع القطان في كتابه أن القرآن الكريم هو معجزة الإسلام الخالدة التي لا يزيدها التقدم العلمي إلا رسوخا في الإعجاز. وهو الكتاب المقدس الرئيسي في الإسلام. والذي يؤمن المسلمون أنه كلام الله المنزل على النبي محمد صلى الله عليه وسلم- للبيان والإعجاز، المنقول عنه بالتواتر والذي يتعبد المسلمون بتلا وته بـ. كان أكثر الناس لايعرفون القرآن معنىا حقيقا مع أنه مهم جدا عند المسلمين، ( افلاً

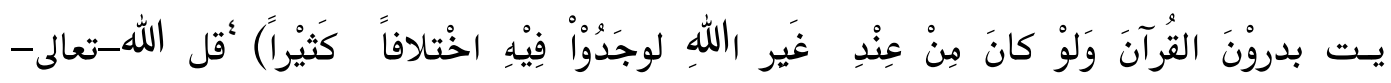
المنافقين بالإعراض عن التدبر في القرآنوَ فهم معانيه المحكمة وألفاظه البليغة فني تدبره يظهر برهانا ويسطع نوره وبيانه ، ولو كان هذا . القرآن مختلفا كما يزعم المشركون والمنافقون لوجدوا فيه تناقضا كبيرا في أخباره ونظمه ومعانيه ولكنه منزه عنذلك فأخباره صدق ، ونظمه بليخ، ومعانيه محكمة، فدل على أنه تنزيل الحكيم الحميده. تبين هذه الأية عن مفهوم التدبر في القرآن حتى نستطيع أن نفهم جيدا كل من الآيات التي نزلها الله فيه ،لأا متتابعة على آيات أخرى، توضح إلى معنوية تامة. نزله الله في العرب فكتب القرآن باللغة العربية لكي يستطيع الناس (العربيون) أن يفهموا معانيه ومقاصده

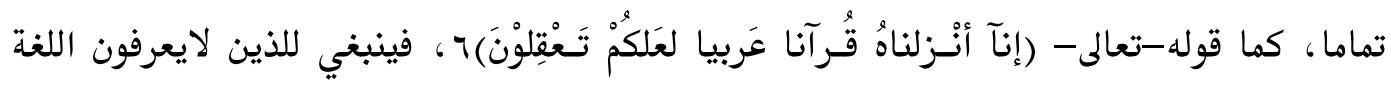
العربية أن يتعلم وا العلوم التي تتعلق، مثل علم النحو والصرف الذين يبحثان في قواعد اللغة. ومن العلوم التي تبحث في جمال القرآن وبداعته الرائعة، من حيث تنظيم الأحرف والكلمات

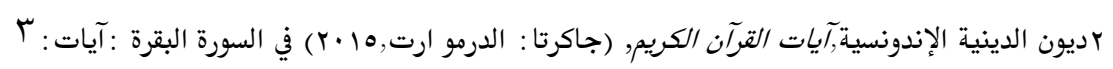

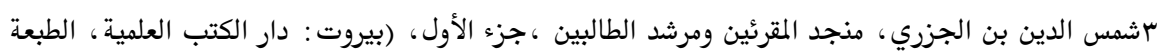

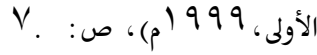

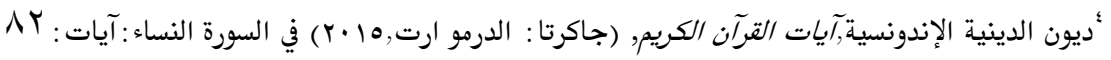

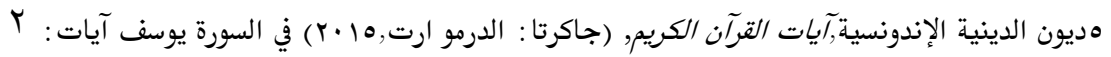

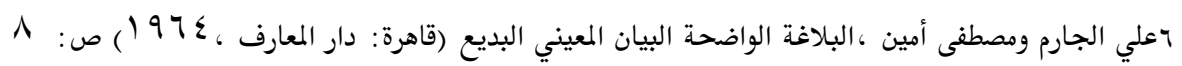

\section{'A Jamiy, Jurnal Bahasa dan Sastra Arab


والأساليب والأفكاروالأنغام علم البلاغة. أما البلاغة فهي تأدية المعنى الجليل واضحا بعبارة صحيحة فصيحة، لها في النفس أثر خلاب، مع ملائمة كل كلام للموطن الذي يقال فيه ،ولأشخاص الذي يخاطبونV. يبحث فيه ثلاثة مباحث المعاني، والبيان، والبديع. علم المعانى هو قواعد يعرفا كيفية مطابقة الكلام مقتضى الحال حتى يكون وفق الغرض الذي سيق له، فبه نحترز

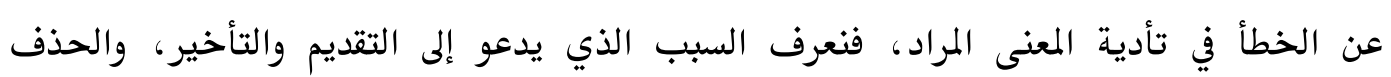
والذكر، والإيجاز حينا والاطناب آخر، والوصل والفصل ؛

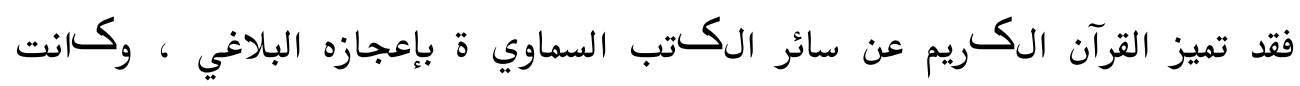
بلاغته مسن الوسـائل المهمة لإ براز إعجاز ه وكشف مكامنه والغوص في بحوره وبيان درره الخفي ة التي يعجز البشر أن يأتوا بمثلها. من هنا كانت قضية الإعجاز البياني من أكثر القضايا

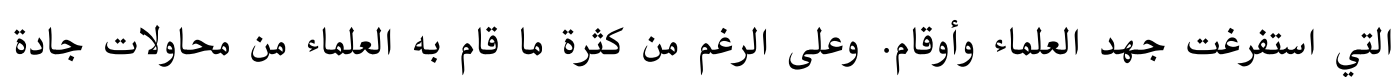
مخلصة في دراسةلغة القرآن الكـريم مسن جوانب متعددة كشفا لأسرارها، وسمات تراكيبها وطرق أدائها، إلا أن لغة القرآن لغة غنية بأفكارهومعانيها وحكهما ومواعظها التي طويت في ثنايا ألفاظها وتراكيبه.ولا يزال القرآن الكريم يعطي كلّ مقبل عليه بمقدار إقباله وقربه ، فكلما زاد القرب زاد العطاء حـتى ولو كان ذلك في الموضوع نفسه. وهذا أمرلا يتصور إلا في القرآن؛ فهو سرمن

فـإن مباحسـث علـم المعساني بوصـفه شـعبة مسن شـعب البلاغــة الـثلاث تبقـى غزى الكرىى. ولاثك في أن موضوع الفصل والوصـل واحسد مسن أهـم موضسوعات علـم المعـاني، بـل مسن أهم موضوعات البلاغة قاطبة، لما ىمتاز به من الحاجة إلى معرفة مواضعه وتمبهىزها ولـذلك قى قـل "إن البلاغة هي معرفة الفصل من الوصل". وفي أهمىة التميىز بكىن الفصل والوصل

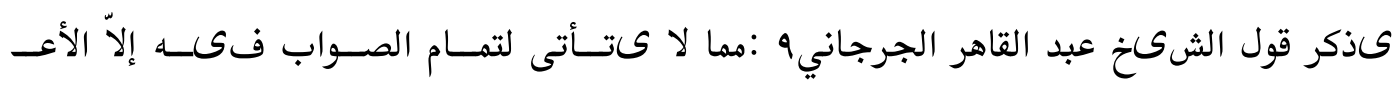

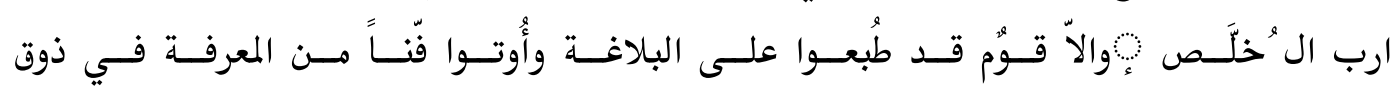

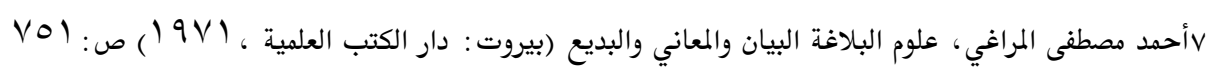

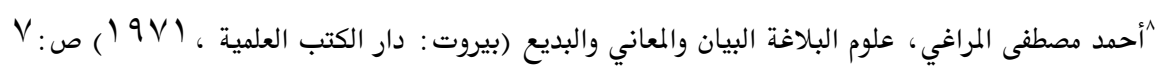

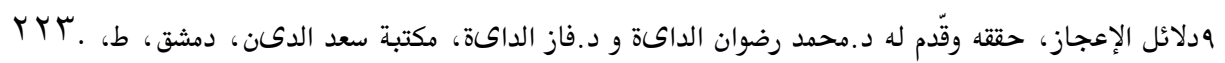

19^V:

\section{'A Jamiy, Jurnal Bahasa dan Sastra Arab \\ Volume 06, No. 2, September 2017}




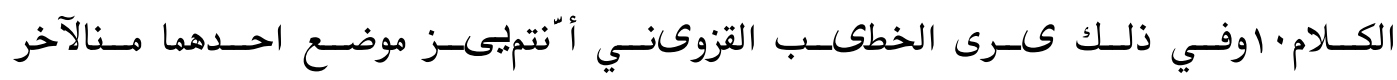

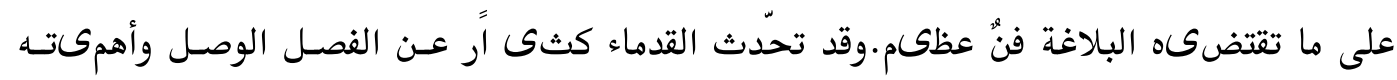

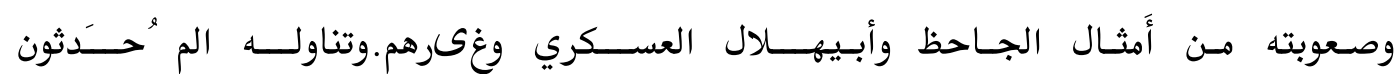

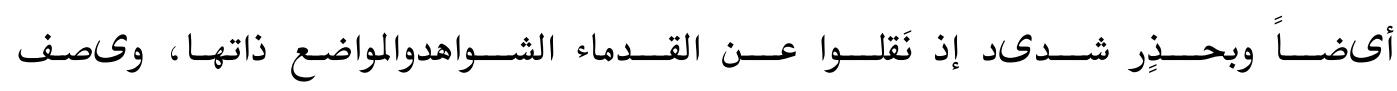

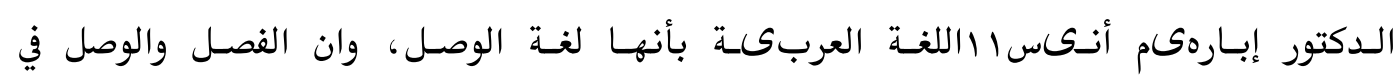

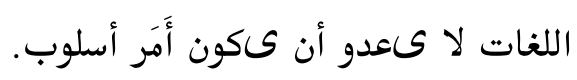

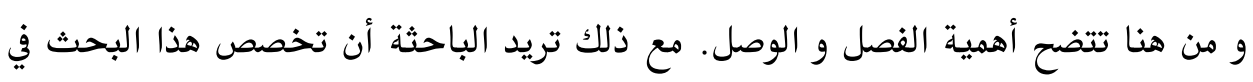

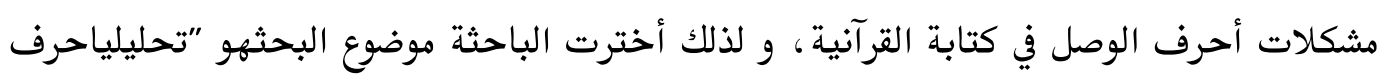

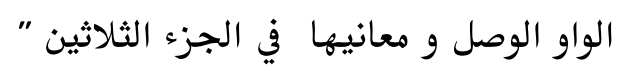

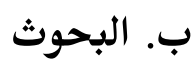
1 ـ موضع احرفواو الوصل في الجزء الثلاثين مواضع الوصل في الجزء الثلاثين رقم اتّحدت الجملتان في الخبرية والإنشائية، لفظاً الجزاء | وعدم مقتضى الوصل

اتّحدت الجملتان في الخبرية والإنشائية، لفظاً

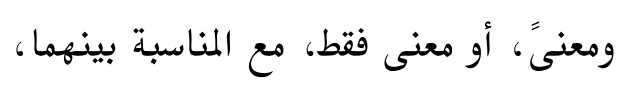
وعدم مقتضى الوصل معنى أو معنى

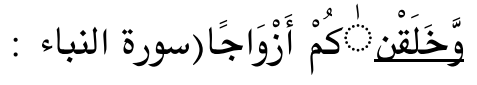

$(\wedge$

اتِحدت الجملتان في الخبرية والإنشائية، لفظاً

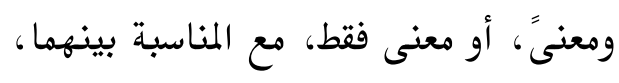

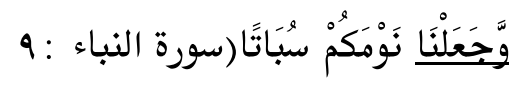
وعدم مقتضى الوصل

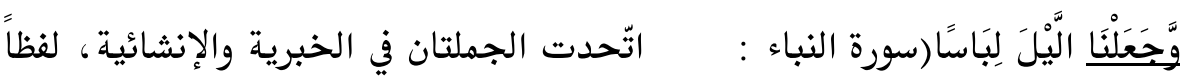

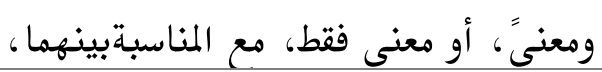
( 1.

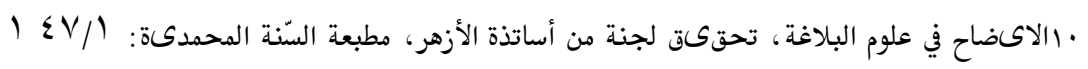

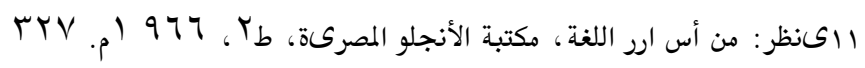

\section{'A Jamiy, Jurnal Bahasa dan Sastra Arab} Volume 06, No. 2, September 2017 


\begin{tabular}{|c|c|c|}
\hline 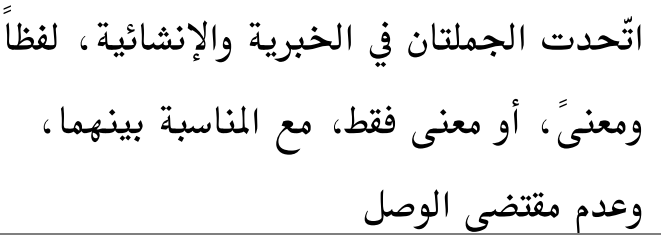 & وَرَحَعَلْنَا النَّهَارَ مَعَاشَا (سورة النباء & 0 \\
\hline واتّحدت الجملتان في الخبرية والإنشائية، لفظاً & 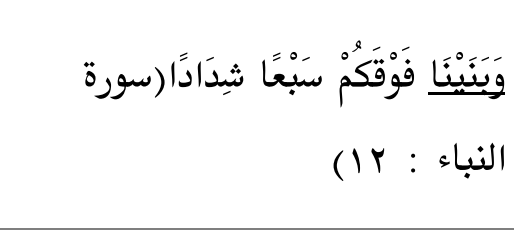 & 9 \\
\hline واتّحدت الجملتان في الخبرية والإنشائية، لفظاً & جًَا وَهََّّاجًا (سورة النباء & V \\
\hline واتِحدت الجملتان في الخبرية والإنشائية، لفظاً & 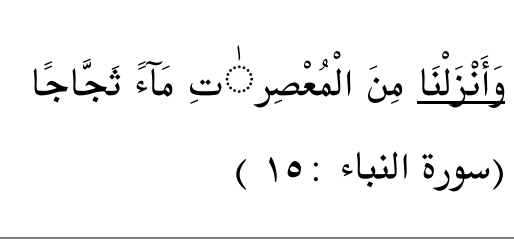 & $\Lambda$ \\
\hline 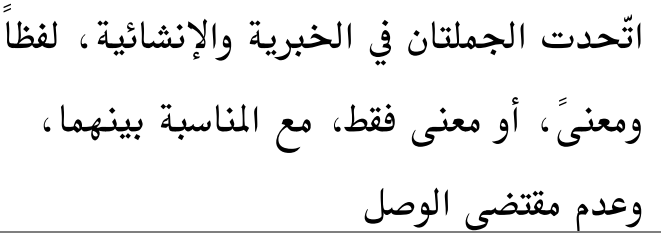 & حَبَّا وَنَبَاتًا (سورة النباء & 9 \\
\hline واتّحدت الجملتان في الخبرية والإنشائية، لفظاً & 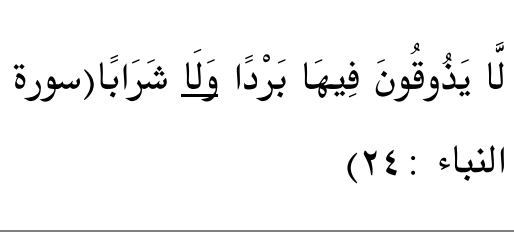 & 1. \\
\hline 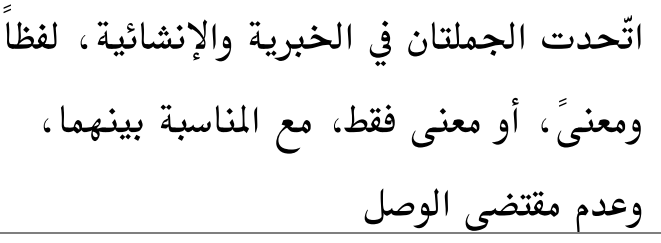 & 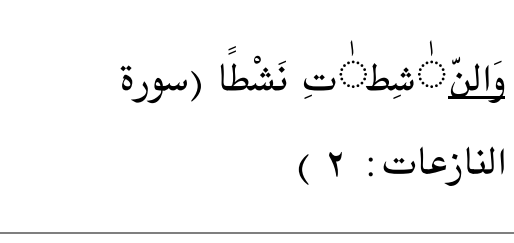 & 11 \\
\hline 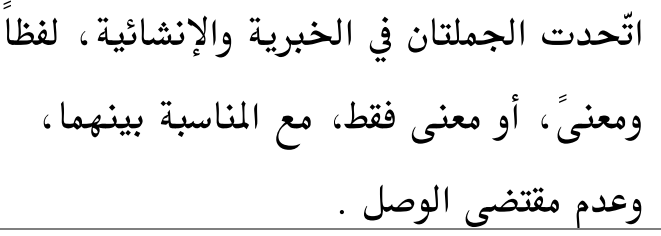 & 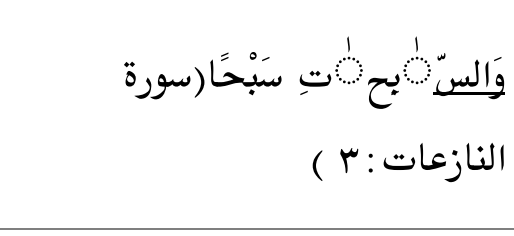 & Ir \\
\hline
\end{tabular}

\section{'A Jamiy, Jurnal Bahasa dan Sastra Arab




\begin{tabular}{|c|c|c|}
\hline كان للجملة الاولى محل من الاعراب، وقصد & 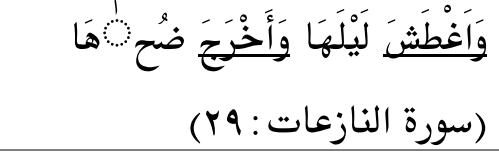 & Ir \\
\hline وعدمنى واتِحدت الجملتان في الخبرية والإنشائية، لفظاً & 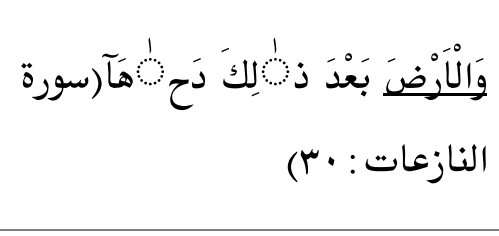 & $1 \varepsilon$ \\
\hline وعدنّ واتِّدت الجملتان في الخبرية والإنشائية، لفظاً & 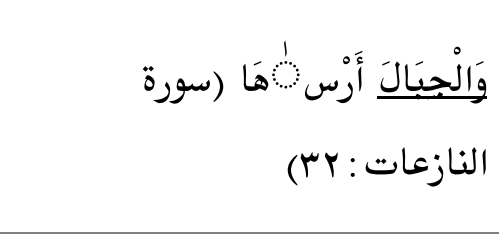 & 10 \\
\hline مشان للجملة الاولى محل من الاعراب، وقصد & 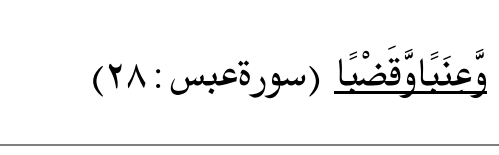 & 17 \\
\hline كان للجملة الاولى محل من الاعراب، وقصد & 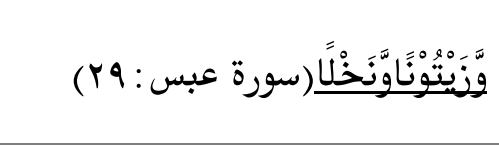 & IV \\
\hline وعدمنى واتِّدت الجملتان في الخبرية والإنشائية، لفظاً & وَحَدَآَيَقَِ غُلْبًا (سورةعبس : •r) & 11 \\
\hline مشان للجملة الاولى محل من الاعراب، وقصد الثانية لها . مشا & 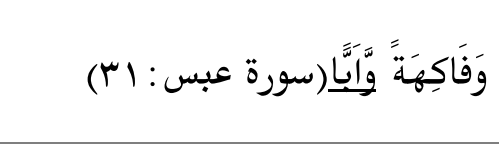 & 19 \\
\hline كان للجملة الاولى محل من الاعراب، وقصد & 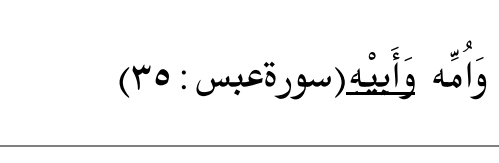 & $r \cdot$ \\
\hline مشان للجملة الاولى محل من الاعراب، وقصد الثانية لها . & وَصَاحِبِتِه وَيَنيْيَ(سورة عبس : بس) & YI \\
\hline وعدمن وعدى أتحدت الجملتان في الخبرية والإنشائية، لفظاً & 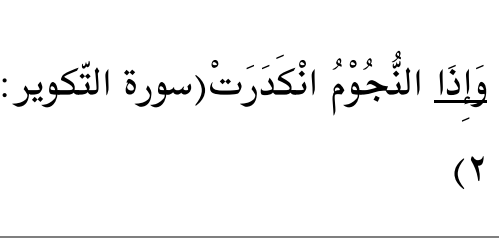 & Yr \\
\hline اتِحدت الجملتان في الخبرية والإنشائية، لفظاً & 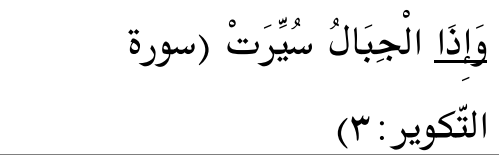 & r \\
\hline
\end{tabular}

\section{'A Jamiy, Jurnal Bahasa dan Sastra Arab}




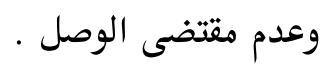

اتّحدت الجملتان في الخبرية والإنشائية ، لفظاً

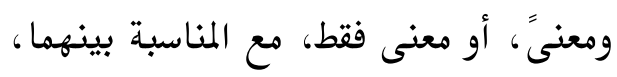

$$
\text { وَإِذَا الْعِشَارُ عُطِّلتْ (سورة }
$$$$
\text { التّكوير: ع ( ) }
$$

$$
\text { وعدم مقتضى الوصل . }
$$

اتّحدت الجملتان في الخبرية والإنشائية ، لفظاً

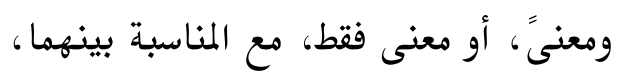

$$
\text { وَإِذَا الْوُحوُشْ حُشَرَتْ (سورة }
$$

$$
\text { وعدم مقتضى الوصل . }
$$

اتّحدت الجملتان في الخبرية والإنشائية، لفظاً

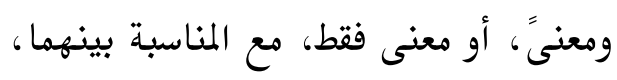

$$
\text { وَرإِذَا الْبحَارُ سُجِّرَتْ (سورة }
$$

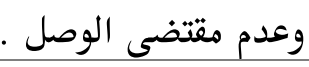

$$
\text { التّكوير : ( ) }
$$

اتِحدت الجملتان في الخبرية والإنشائية، لفظاً

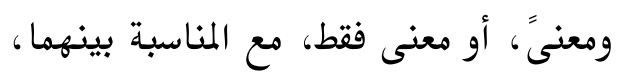

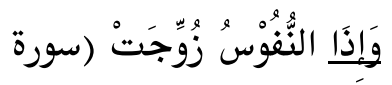

$$
\text { وعدم مقتضى الوصل . }
$$

$$
\text { (V: التّكوير }
$$

اتّحدت الجملتان في الخبرية والإنشائية، لفظاً

ومعنى"، أو معنى فقط، مع المناسبة بينهما،

$$
\text { وَرإِذَا الصُّحُفْ نُشِرَتْ (سورة }
$$

$$
\text { التّكوير: · (1) (1) }
$$

$$
\text { وعدم مقتضى الوصل . }
$$

اتّحدت الجملتان في الخبرية والإنشائية، ، لفظاً

ومعنى"، أو معنى فقط، مع المناسبة بينهما ،

$$
\text { وَإِذَا السَّمَاء كُشِطَتْ (سورة }
$$

$$
\text { التّكوير: (1) }
$$

$$
\text { وعدم مقتضى الوصل . }
$$

اتّحدت الجملتان في الخبرية والإنشائية، لفظاً

ومعنى"، أو معنى فقط، مع المناسبة بينهما،

$$
\begin{aligned}
& \text { وَإِذَا الْجَحَيْمِ سُعِّرَتْ (سورة }
\end{aligned}
$$

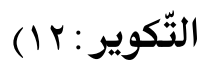

$$
\text { وعدم مقتضى الوصل . }
$$

اتّحدت الجملتان في الخبرية والإنشائية، لفظاً

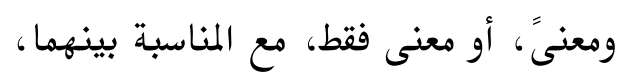

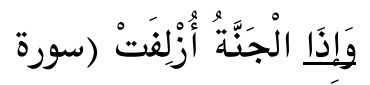

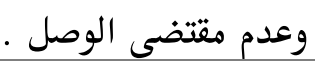

\section{'A Jamiy, Jurnal Bahasa dan Sastra Arab}




$$
\begin{aligned}
& \text { اتِحدت الجملتان في الخبرية والإنشائية، لفظاً }
\end{aligned}
$$

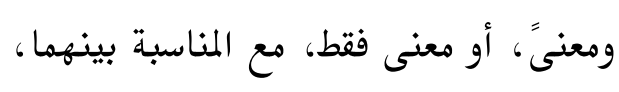

$$
\begin{aligned}
& \text { وعدم مقتضى الوصل . } \\
& \text { وَالَّْْل إذَا عَسْعَسَ (سورة } \\
& \text { ( التّكوير: إن }
\end{aligned}
$$

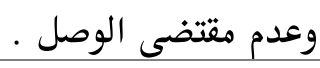

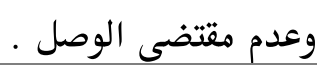

اتّحدت الجملتان في الخبرية والإنشائية، لفظاً

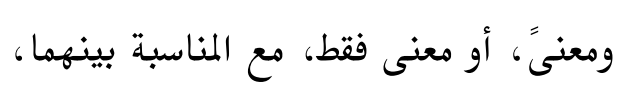

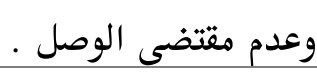

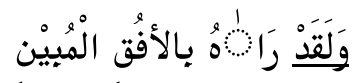

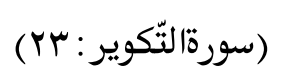

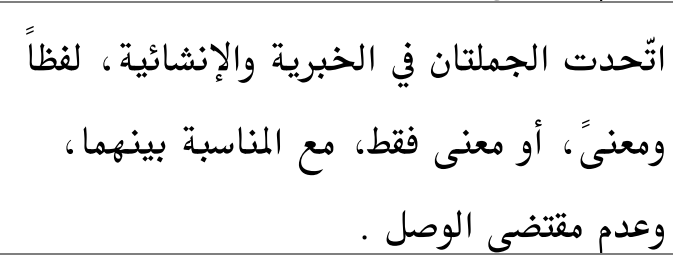

وَمَا هوَ عَلَى الْغَيْبِ بضَنَيْنِ (سورة

التّكوير: گr)

mq

اتّحدت الجملتان في الخبرية والإنشائية، لفظاً

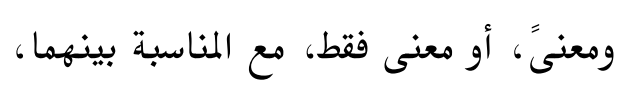

اتِّحدت الجملتان في الخبرية والإنشائية، لفظاً

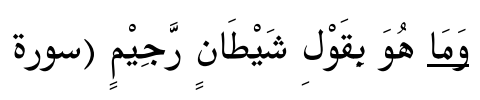

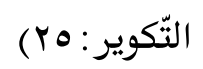

mV

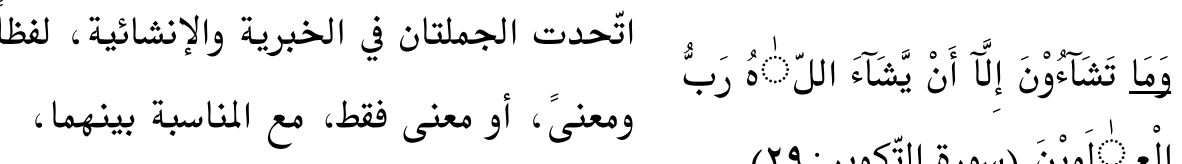

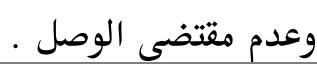

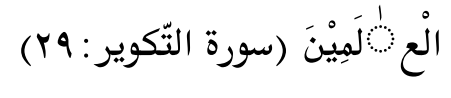

rı

$$
\begin{aligned}
& \text { اتِّحدت الجملتان في الخبرية والإنشائية، لفظاً }
\end{aligned}
$$

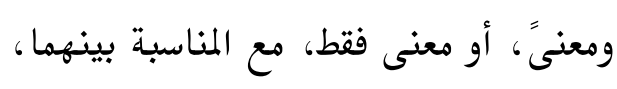

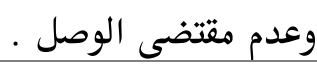$$
\text { وَاِذِاً الْكَوَاكِبْ انْتَثَرَتْ (سورة }
$$$$
\text { (r: الانفطار }
$$

$p q$

اتِّحدت الجملتان في الخبرية والإنشائية، لفظاً

ومعنى، أو معنى فقط، مع المناسبة بينهما،

وَرإِذَا الْحَحَرُ فُجِّرَتْ (سورة

الانفطار : r) 


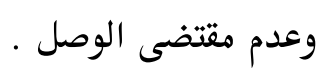

اتّحدت الجملتان في الخبرية والإنشائية ، لفظاً

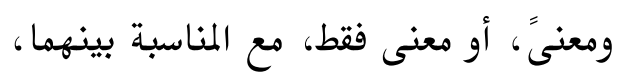

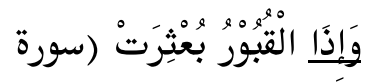

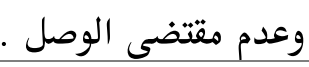

الانفطار : ؟)

اتّحدت الجملتان في الخبرية والإنشائية ، لفظاً

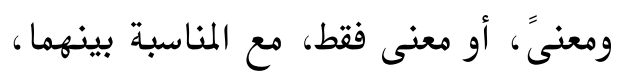
وََإِنَّ الََُّْْارَ لَفِيْ جَحَيْمِ

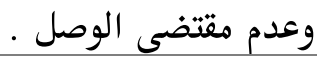

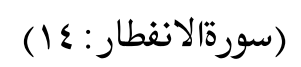

اتّحدت الجملتان في الخبرية والإنشائية، لفظاً

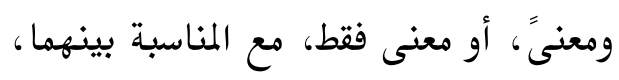

$$
\text { وَمَا هُمْ عَنْهَا بِغَآيَيْيْنَ (سورة }
$$

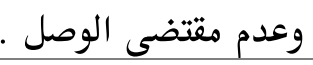

اتّحدت الجملتان في الخبرية والإنشائية، لفظاً

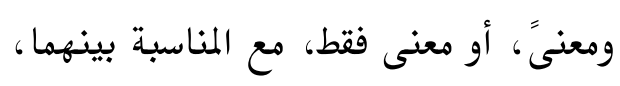

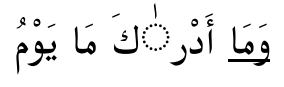

$$
\text { وعدم مقتضى الوصل . }
$$

اتّحدت الجملتان في الخبرية والإنشائية، لفظاً

ومعنى"، أو معنى فقط، مع المناسبة بينهما،

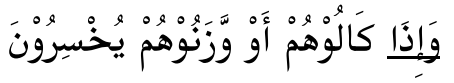

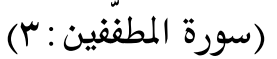

$$
\text { وعدم مقتضى الوصل . }
$$

اتّحدت الجملتان في الخبرية والإنشائية ، لفظاً

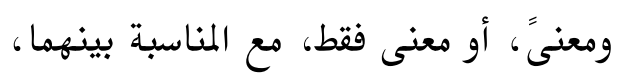

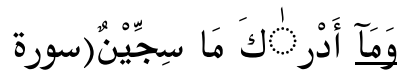

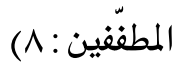

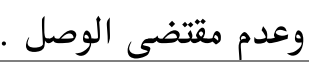

اتِحدت الجملتان في الخبرية والإنشائية، لفظاً

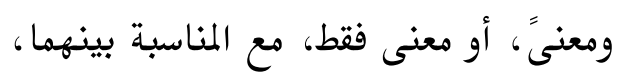

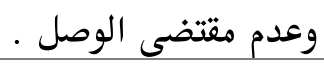

وَمَا يُكَذَّبُ به إِلَّ كُلْ مُعْتَدِ

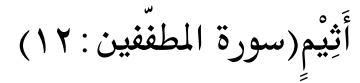

اتّحدت الجملتان في الخبرية والإنشائية ، لفظاً

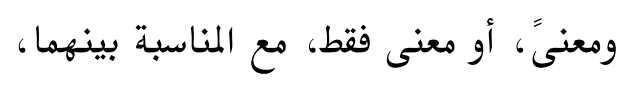

$$
\text { وَمَاَ أَدْرِ أَكَ مَا عِلِّيُونَنَ (سورة }
$$

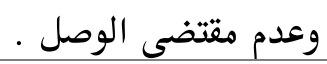

\section{'A Jamiy, Jurnal Bahasa dan Sastra Arab}


كان للجملة الاولى محل من الاعراب، وقصد

$$
\text { مشاركة الثانية لها }
$$

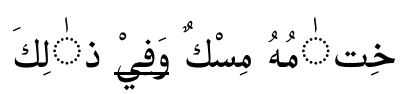

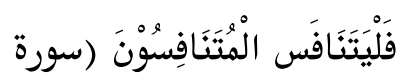

$\varepsilon 9$

(Y المطفّفين (Y)

اتّحدت الجملتان في الخبرية والإنشائية، لفظاً

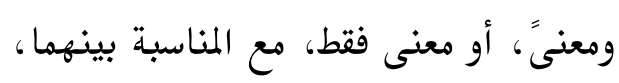

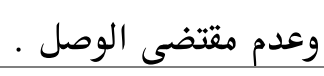

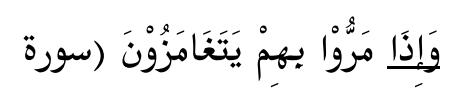

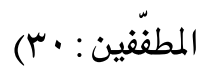

๑.

اتّحدت الجملتان في الخبرية والإنشائية، لفظاً

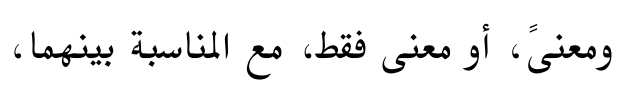

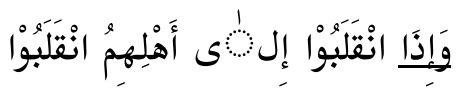

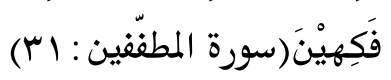

01

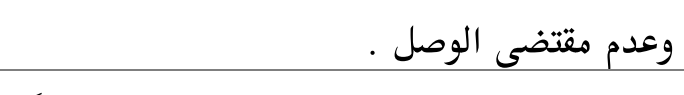

اتّحدت الجملتان في الخبرية والإنشائية، لفظاً

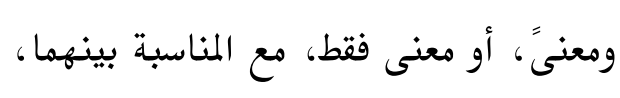

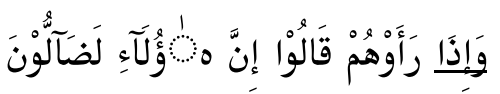

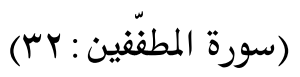

$$
\text { - وعدم مقتضى الوصل . اتحدت الجملتان في الخبرية والإنشائية، }
$$$$
\text { لفظاً ومعنى" أو معنى فقط، مع المناسبة آجدية }
$$$$
\text { بينهما، وعدم مقتضى الوصل . }
$$

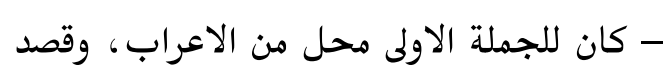

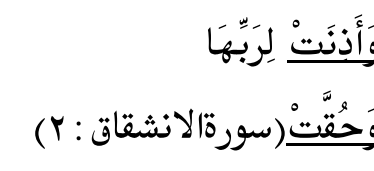

مشاركة الثانية لها

- اتّحدت الجملتان في الخبرية والإنشائية، ،

لفظاً ومعنى"، أو معنى فقط، مع المناسبة الجمدية

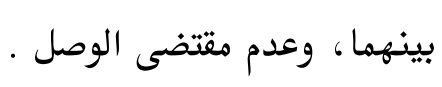

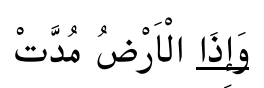

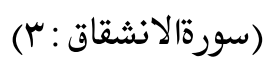

or

- كان للجملة الاولى محل من الاعراب، وقصد

مشاركة الثانية لها

- اتّحدت الجملتان في الخبرية والإنشائية ،

لفظاً ومعنى؛، أو معنى فقط، مع المناسبة وَأَلَقْتِتْ مَا فِيْهَا وَتَخَلَّتْْ

بينهما، وعدم مقتضى الوصل .

(سورةالانشقاق : §)

- كان للجملة الاولى محل من الاعراب، وقصد

\section{'A Jamiy, Jurnal Bahasa dan Sastra Arab}

Volume 06, No. 2, September 2017 
مشاركة الثانية لها

- اتّحدت الجملتان في الخبرية والإنشائية،

لفظاً ومعنى" أو معنى فقط، مع المناسبة

بينهما، وعدم مقتضى الوصل .

وَأَذْنَتْ لِربِِهَا وَحُقَّتَّْ (سورةالانشقا :

07

- كان للجملة الاولى محل من الاعراب، وقصد

مشاركة الثانية لها

- اتّحدت الجملتان في الخبرية والإنشائية،

لفظاً ومعنى"، أو معنى فقط، مع المناسبة

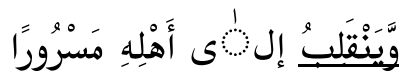

بينهما، وعدم مقتضى الوصل .

(سورة/انشقا : 9)

ov

- اتّحدت الجملتان في الخبرية والإنشائية،

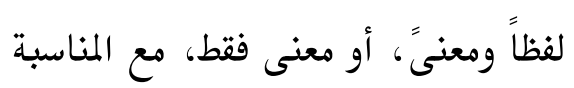

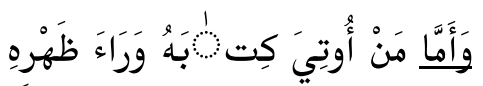

بينهما، وعدم مقتضى الوصل .

(سورة/لانشقا: (1)

وَالَّْْل وَمَا وَسَقَ (سورةالانشقا : IV ) ومعنىَ، أو معنى فقط، مع المناسبة بينهما،

89

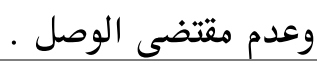

اتّحدت الجملتان في الخبرية والإنشائية، لفظاً

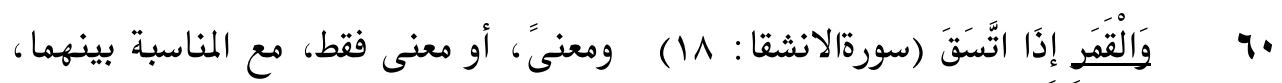

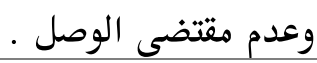

اتّحدت الجملتان في الخبرية والإنشائية، لفظاً

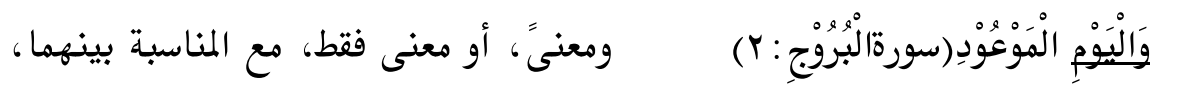
71

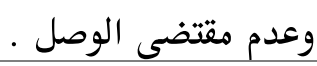

اتّحدت الجملتان في الخبرية والإنشائية، لفظاً

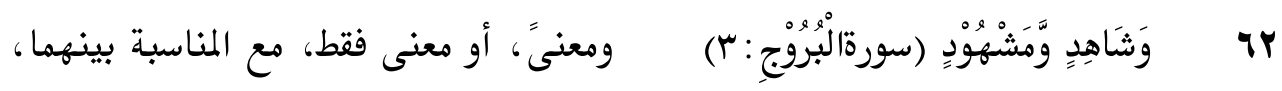

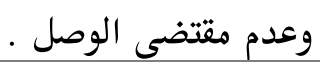

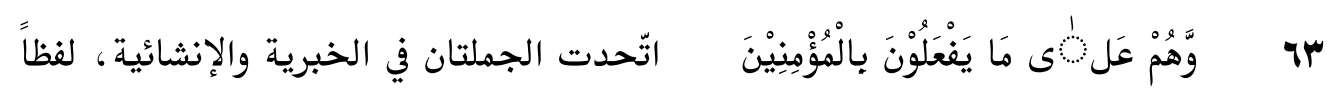

'A Jamiy, Jurnal Bahasa dan Sastra Arab

Volume 06, No. 2, September 2017 


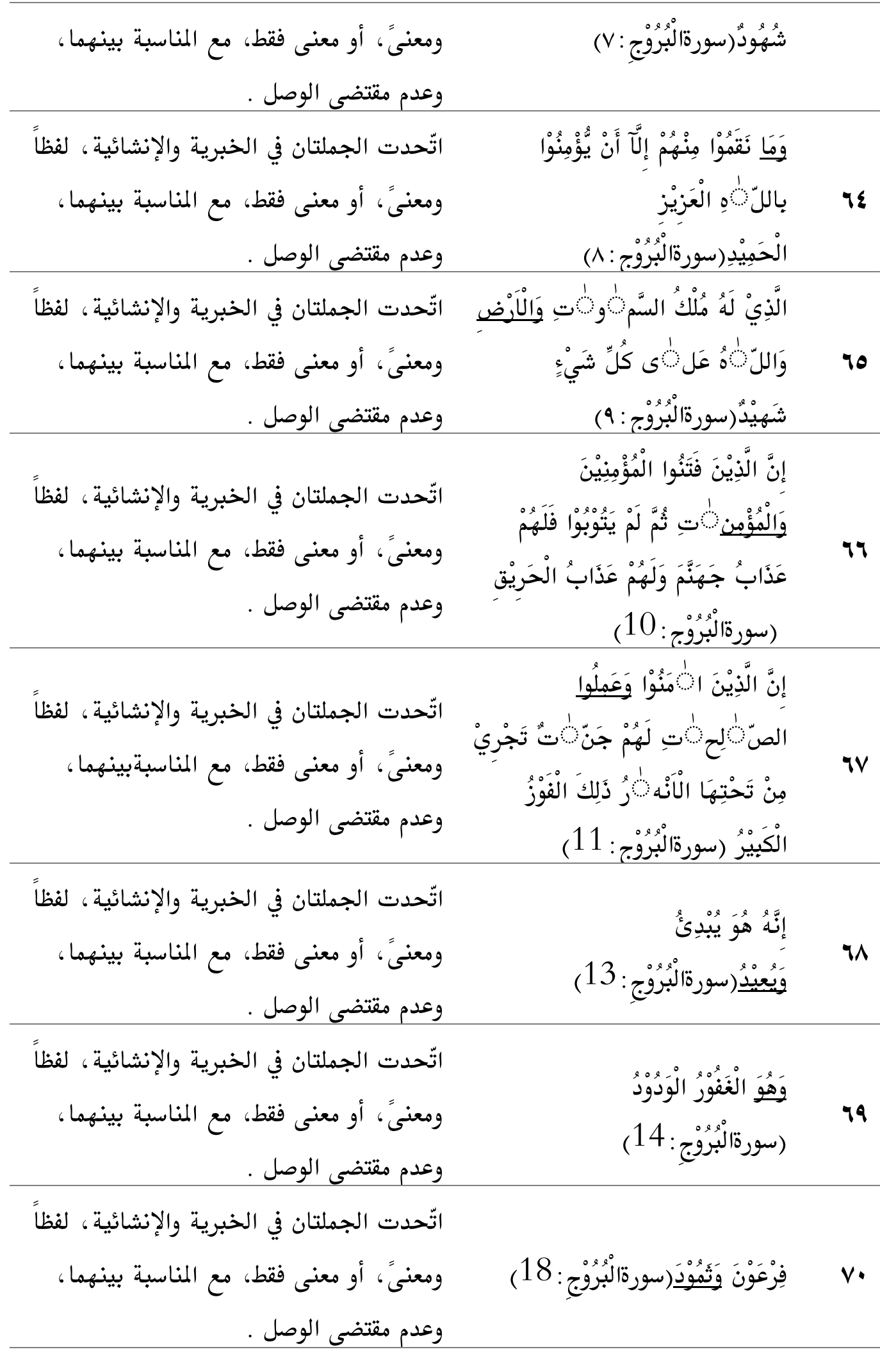

\section{'A Jamiy, Jurnal Bahasa dan Sastra Arab Volume 06, No. 2, September 2017}


اتّحدت الجملتان في الخبرية والإنشائية، لفظاً

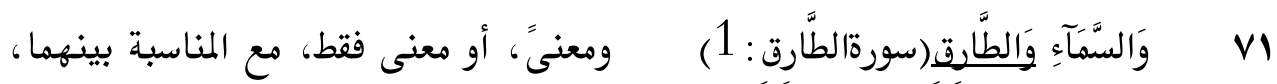

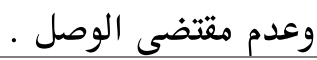

اتّحدت الجملتان في الخبرية والإنشائية ، لفظاً

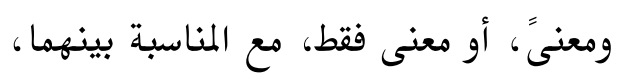
وَمَاَ أَدْرِ رلَكَ مَا الطَّرقُ

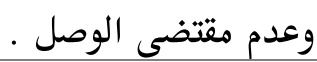

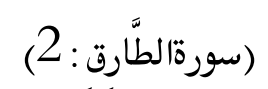

VY

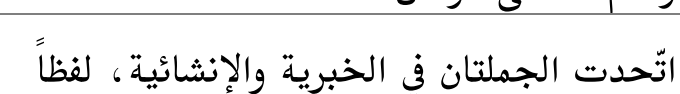

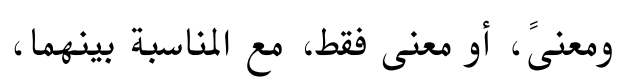

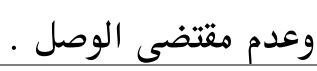

اتّحدت الجملتان في الخبرية والإنشائية، لفظاً

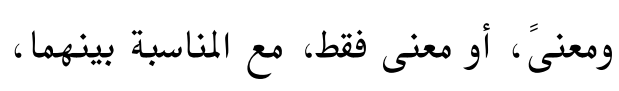
اتّحدت الجملتان في الخبرية والإنشائية ، لفظاً فَمَاَ لَهُ مِنْ قُوَّةٍ وَلَِ نَاصِرِ

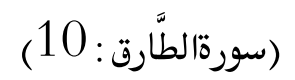

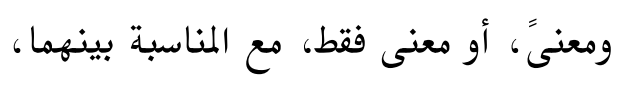
وعدم مقتضى الوصل . وَالْْرَضِ ذَاتِ الصَّدْعِ (سورةالطَّرق : 12 ) vo اتِحدت الجملتان في الخبرية والإنشائية ، لفظاً

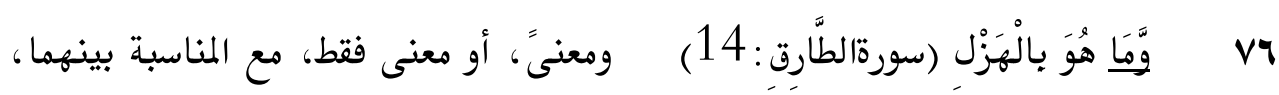

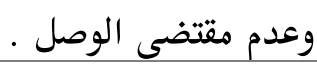

اتّحدت الجملتان في الخبرية والإنشائية، لفظاً

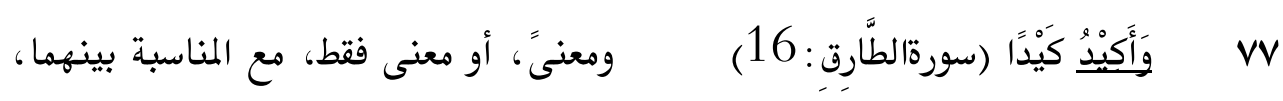

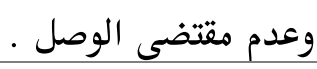

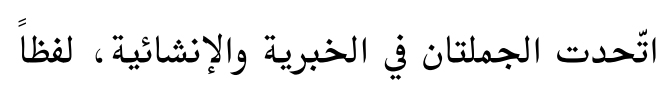

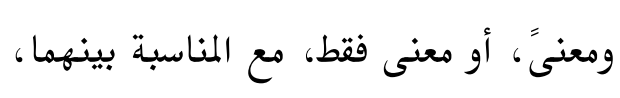

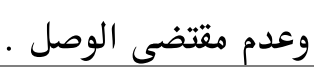

اتّحدت الجملتان في الخبرية والإنشائية، لفظاً

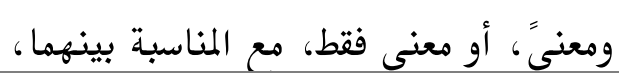

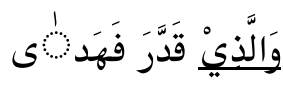

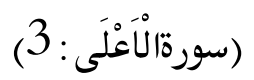
V^ va

'A Jamiy, Jurnal Bahasa dan Sastra Arab Volume 06, No. 2, September 2017 


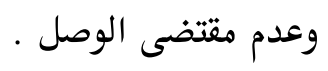

اتَحدت الجملتان في الخبرية والإنشائية، لفظاً

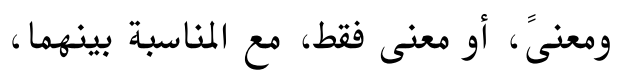

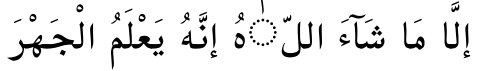

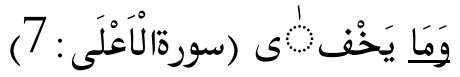

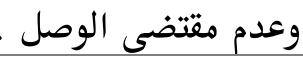

اتّحدت الجملتان في الخبرية والإنشائية، لفظاً

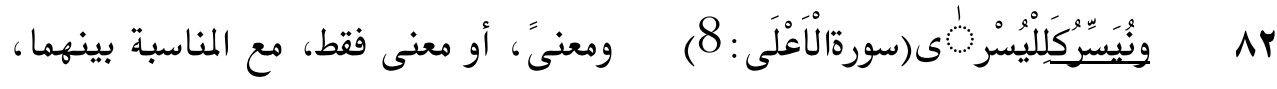

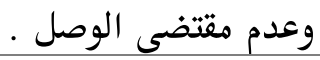

اتّحدت الجملتان في الخبرية والإنشائية، لفظاً

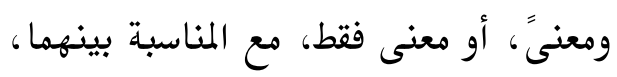

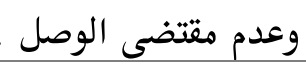

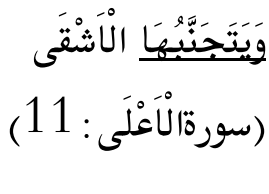

اتّحدت الجملتان في الخبرية والإنشائية، لفظاً

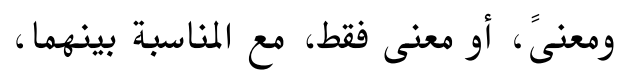
وعدم مقتضى الوصل .

اتّحدت الجملتان في الخبرية والإنشائية، لفظاً

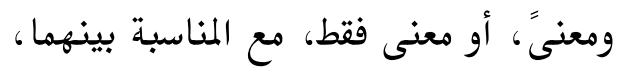

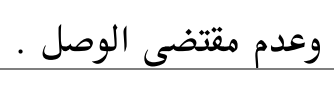

اتّحدت الجملتان في الخبرية والإنشائية، لفظاً

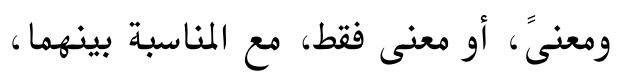

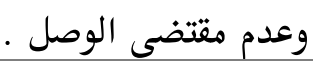

اتّحدت الجملتان في الخبرية والإنشائية، لفظاً

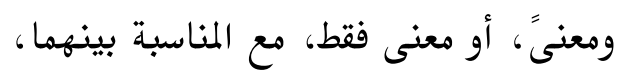


اتّحدت الجملتان في الخبرية والإنشائية، لفظاً

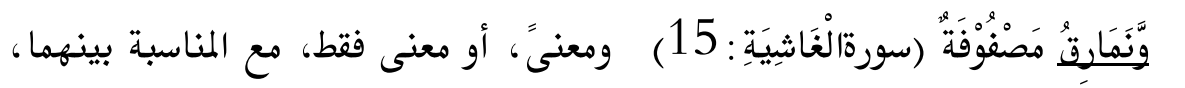

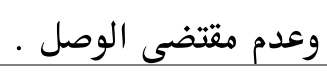

اتّحدت الجملتان في الخبرية والإنشائية، لفظاً

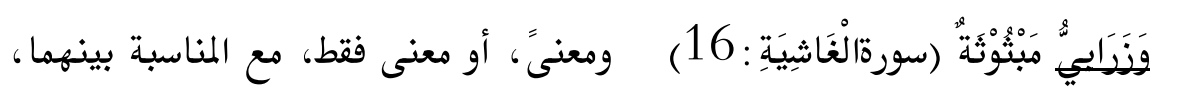

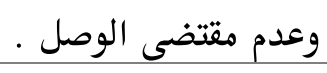

اتّحدت الجملتان في الخبرية والإنشائية ، لفظاً

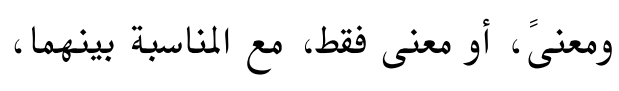

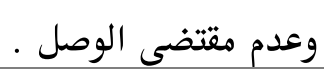

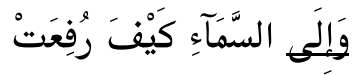

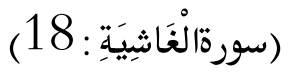

91

اتّحدت الجملتان في الخبرية والإنشائية، لفظاً

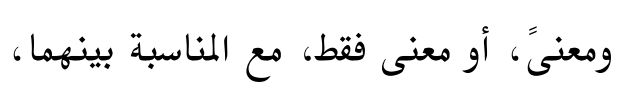

اتّحدت الجملتان في الخبرية والإنشائية، لفظاً

وَالِلَى الْجِبَال كَيْفَ نُصِبَتْ

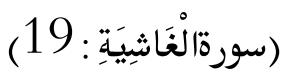

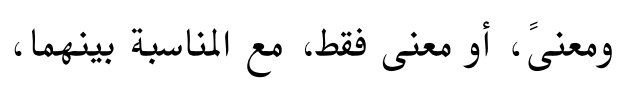

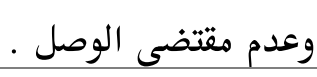
وَإِلَى الَْرْضِ كَيْفَ سُطِحَتْ (سورةالْغَاشِيَةِ : 20)

اتّحدت الجملتان في الخبرية والإنشائية، لفظاً

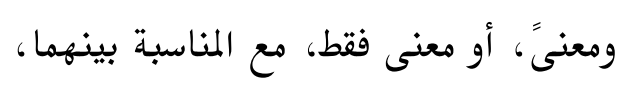
وعدم مقتضى الوصل .

إلَّاَ مَنْ تَوَلَّلَ وَكَفَ) سورةالْغَاشِيَِة:

اتِحدت الجملتان في الخبرية والإنشائية، لفظاً

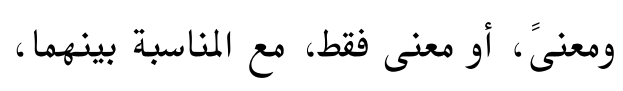
وَلَيَال عَشْرِ (سورةالْفَجْرِ : r) 90 وعدم مقتضى الوصل .

اتِحدت الجملتان في الخبرية والإنشائية، لفظاً

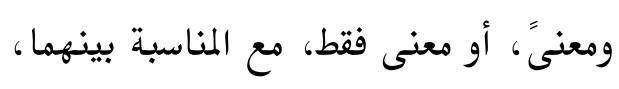

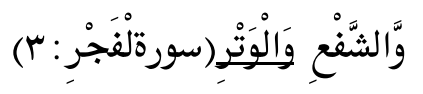
99 وعدم مقتضى الوصل .

اتّحدت الجملتان في الخبرية والإنشائية ، لفظاً ومعنى"، أو معنى فقط، مع المناسبة بينهما، 


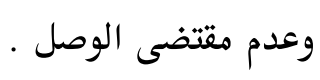

اتّحدت الجملتان في الخبرية والإنشائية، لفظاً

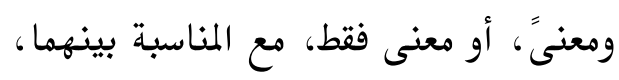

وَفرْعَوَنْنَ ذِى الَْوتَنَادِ

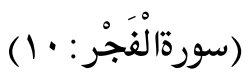

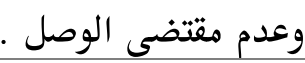

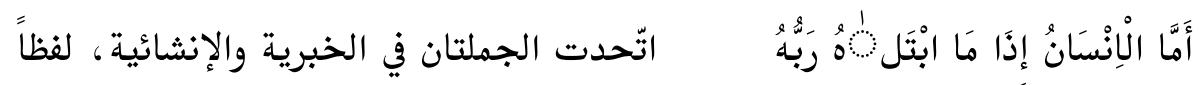

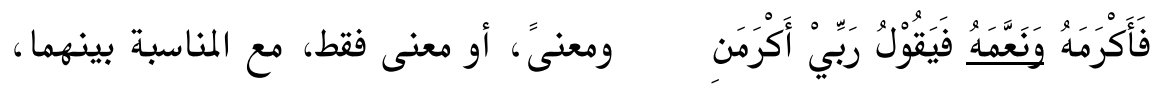

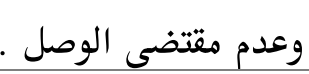

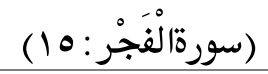

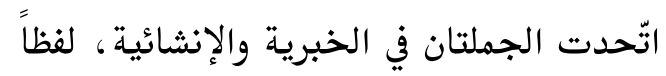

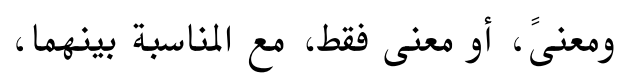
وعدم مقتضى الوصل .

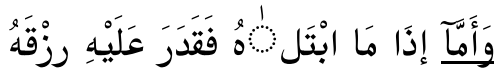

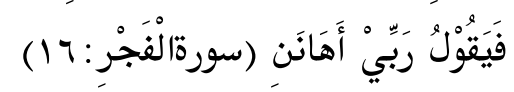

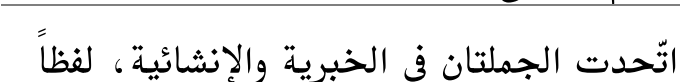

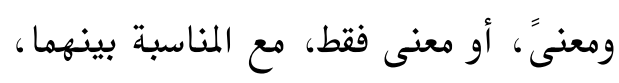

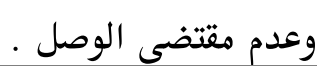

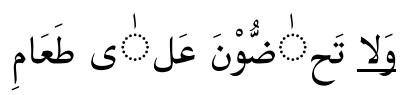

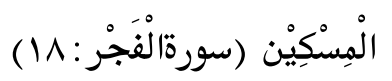

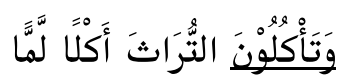

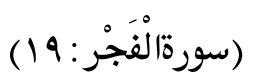

$1 \cdot r$

ومعنى"، أو معنى فقط، مع المناسبة بينهما، الجهدل وعدم مقتضى الوصل .

اتّحدت الجملتان في الخبرية والإنشائية، لفظاً

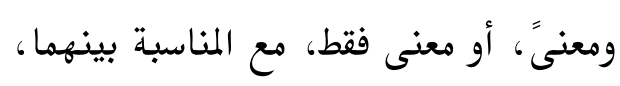

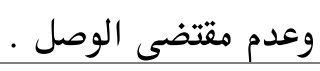

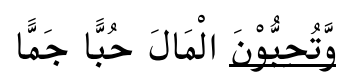

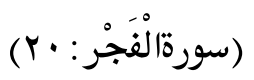
$1 \cdot \mu$

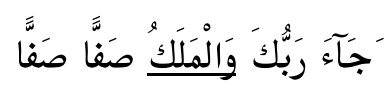

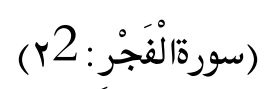
$1 \cdot \varepsilon$

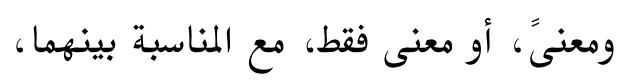

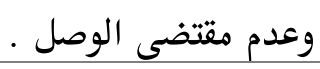

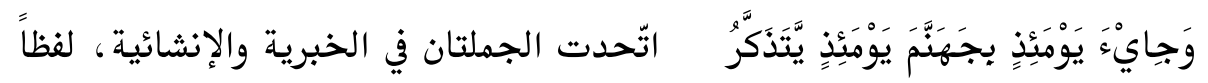

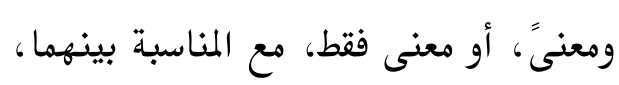

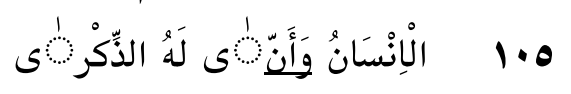

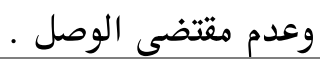

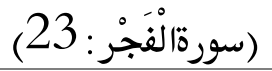

\section{'A Jamiy, Jurnal Bahasa dan Sastra Arab} Volume 06, No. 2, September 2017 


$$
\begin{aligned}
& \text { اتّحدت الجملتان في الخبرية والإنشائية ، لفظاً }
\end{aligned}
$$

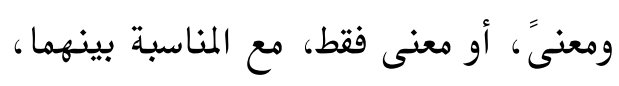

$$
\begin{aligned}
& \text { وعدم مقتضى الوصل . }
\end{aligned}
$$

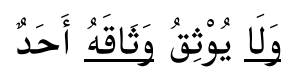

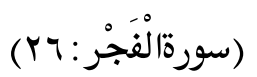

$$
\begin{aligned}
& \text { وعدم مقتضى الوصل . و ل }
\end{aligned}
$$

اتّحدت الجملتان في الخبرية والإنشائية، لفظاً

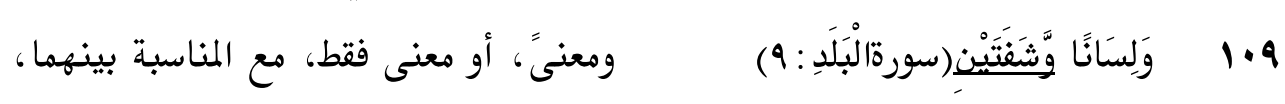

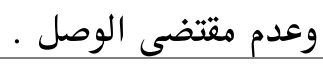

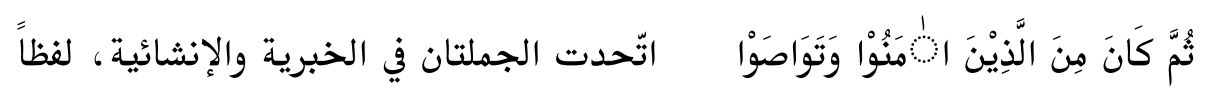

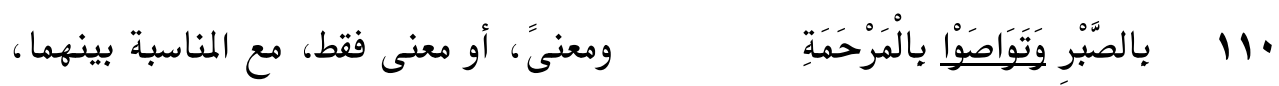

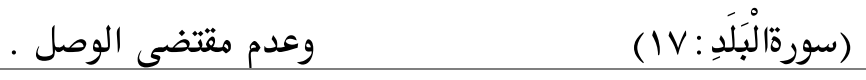

اتّحدت الجملتان في الخبرية والإنشائية ، لفظاً

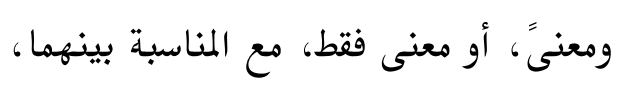

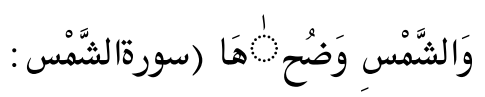
وعدم مقتضى الوصل .

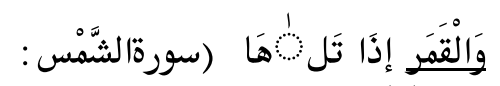

اتِحدت الجملتان في الخبرية والإنشائية، لفظاً

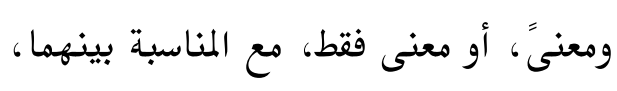
وعدم مقتضى الوصل .

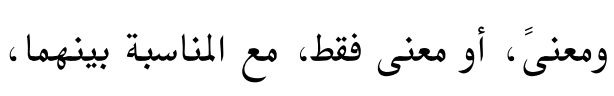
وعدم مقتضى الوصل .

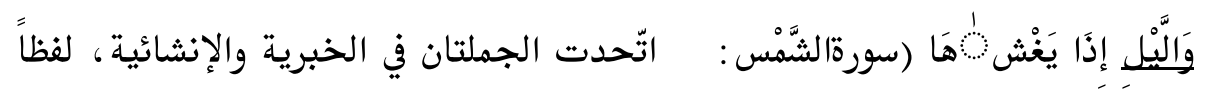
ومعنى، أو معنى فقط، مع المناسبة بينهما، 


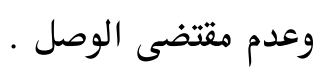

اتِحدت الجملتان في الخبرية والإنشائية، لفظاً

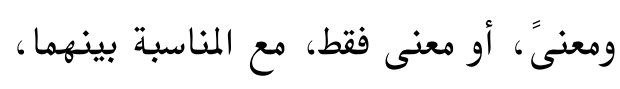

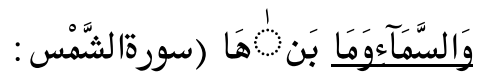

110 وعدم مقتضى الوصل .

اتّحدت الجملتان في الخبرية والإنشائية، لفظاً

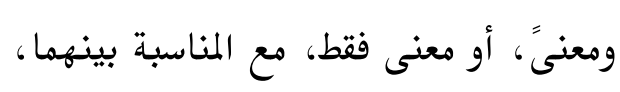
وعدم مقتضى الوصل .

اتِحدت الجملتان في الخبرية والإنشائية، لفظاً

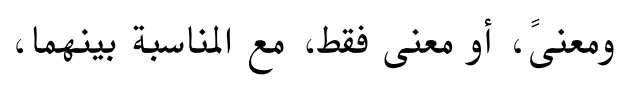

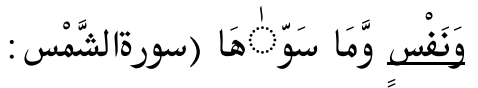
وعدم مقتضى الوصل .

فَأَلْهَمَهَا فُجُوْرَهَا وَتَقْوِ لِهَا

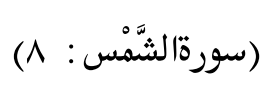

ومعنى"، أو معنى فتط، مع المناسبة بينهما ، وَقَدْ خَابَ مَنْ دَسِّهَ

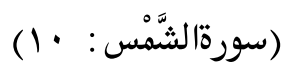

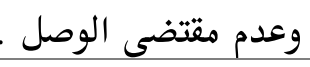

اتّحدت الجملتان في الخبرية والإنشائية، لفظاً

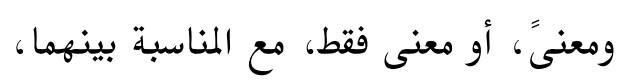

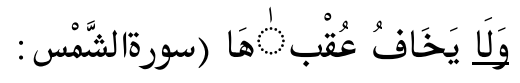
وعدم مقتضى الوصل . - و وَالنَّهَار إذَا تَجَلَّلى (سورةالَّل :

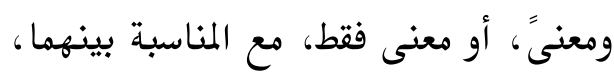

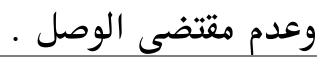

اتِحدت الجملتان في الخبرية والإنشائية، لفظاً

ومعنى"، أو معنى فقط، مع المناسبة بينهما،

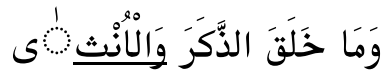

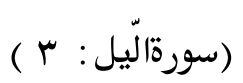

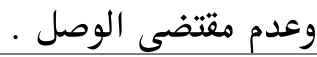


rr.

\begin{tabular}{|c|c|c|}
\hline 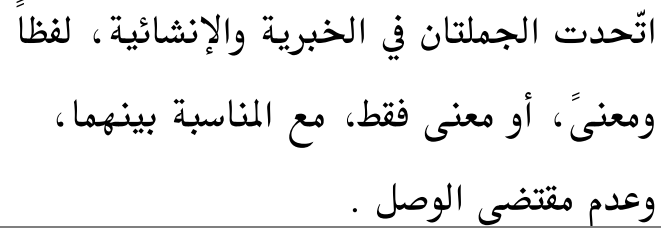 & 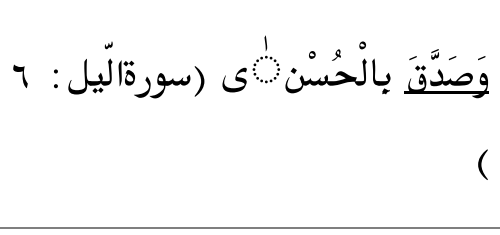 & سY \\
\hline وعدّحدت الجملتان في الخبرية والإنشائية، لفظاً & 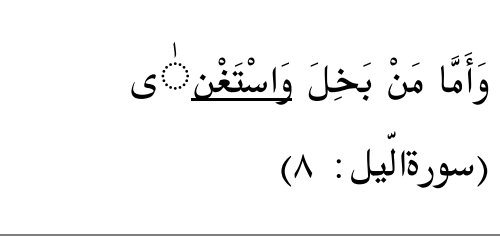 & IYE \\
\hline وعدّحدت الجملتان في الخبرية والإنشائية، لفظاً & لـ (سورةاليل : 9) & Iro \\
\hline 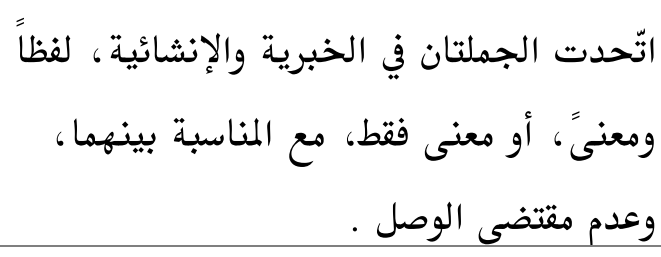 & ا مَالهُ إذًَا تَرَدِّلَى & IYq \\
\hline وعدمدم اتّحدت الجملتان في الخبرية والإنشائية، لفظاً & 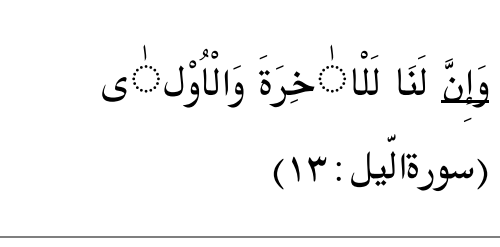 & $I Y V$ \\
\hline 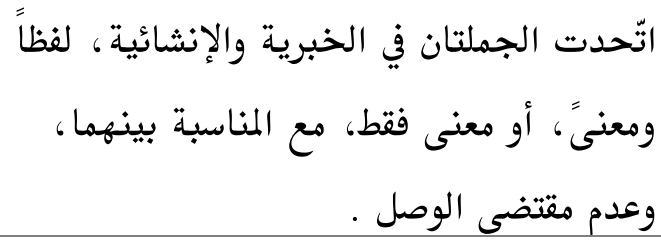 & 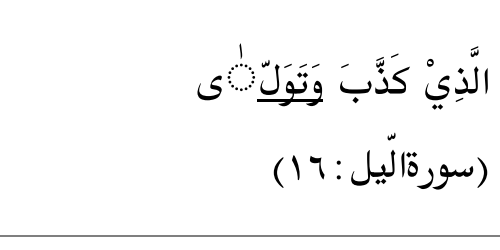 & $I Y \Lambda$ \\
\hline 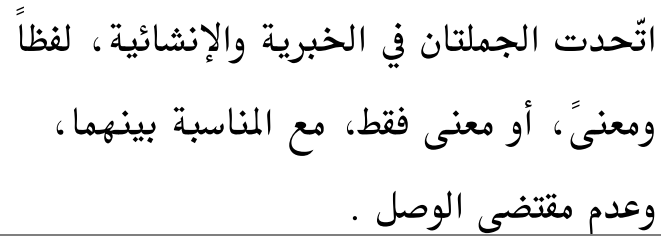 & وَالكا & 179 \\
\hline 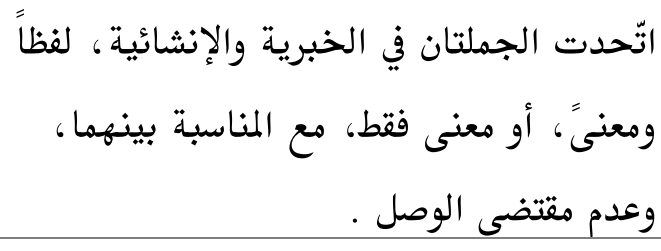 & 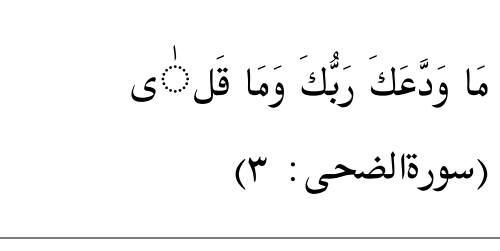 & Ir. \\
\hline اتّحدت الجملتان في الخبرية والإنشائية، لفظاً & 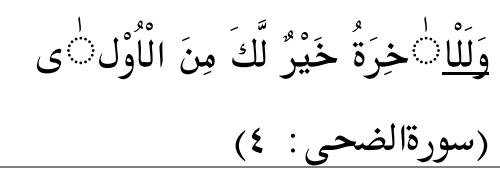 & $\mid$ \\
\hline
\end{tabular}

'A Jamiy, Jurnal Bahasa dan Sastra Arab

Volume 06, No. 2, September 2017 


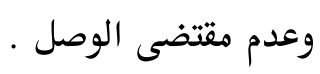

اتّحدت الجملتان في الخبرية والإنشائية، لفظاً

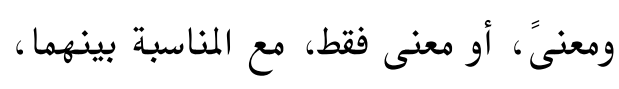

$$
\begin{aligned}
& \text { وَلَسَوْفَ يُعْطِيْكَ رَبُكَ } \\
& \text { فَتَرْض لِى (سورة الضحى : ه ) }
\end{aligned}
$$

Irr

$$
\begin{aligned}
& \text { اتّحدت الجملتان في الخبرية والإنشائية، لفظًاً لوصل . }
\end{aligned}
$$

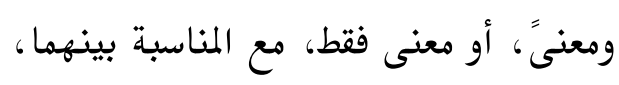

$$
\text { وَوَجَدَكَ ضَآلَّا فَهَدَّى }
$$$$
\text { ( V : سورة لضحى) }
$$

irr

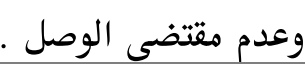

$$
\begin{aligned}
& \text { اتّحدت الجملتان في الخبرية والإنشائية، لفظاً }
\end{aligned}
$$

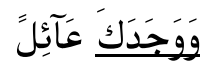

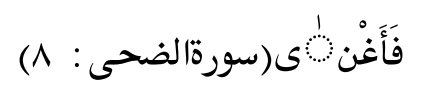

Irs

اتِحدت الجملتان في الخبرية والإنشائية، لفظاً

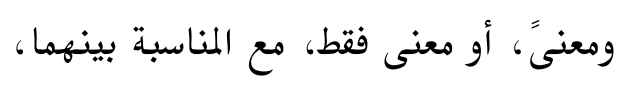

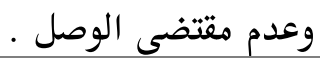
وَأَمَّا السَّآَئَلَ فَلَّا

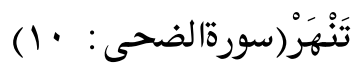
ito

وَأَمَّاً يِنِعْمَةِ رَبِّكَ

فَحَدِّثْ سورة الضحى :

Iry

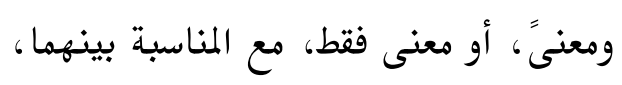
وعدم مقتضى الوصل .

اتِحدت الجملتان في الخبرية والإنشائية، لفظاً

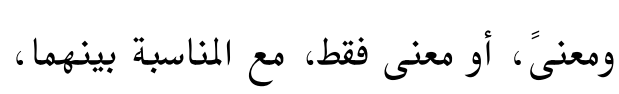
وَوَضَعْنَا عَنْكَكَ وِزْرَكَ(سورةالانشراح:

IrV

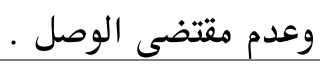

اتِحدت الجملتان في الخبرية والإنشائية، لفظاً

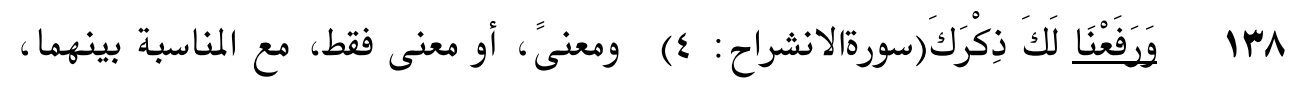

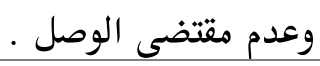

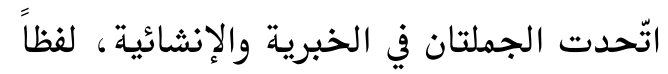

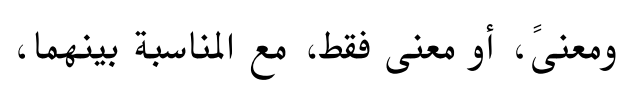

$$
\begin{aligned}
& \text { وَالِ لِى رَبِكَ } \\
& \text { فَرَرغَبْ سورةالانشراح : ^ }
\end{aligned}
$$


واتفق مع ما ذهب إليه بعض الباحثين من أن بلاغة الوصل لا تقتصر على (الواو) فحسب بل يمكن لها أن تتحقق على مستوى حروف العطف الأخرى، لما تتمثع يه هذه الحروف من طاقات دلالية تزيد من بلاغة العطف في النص، إذ (إننا لا نعدم وجوها دقيقة أمورا خفية نجدها كامنة وراء العطف بغير الواو). كما اشترطوا في العطف كي يكون سائغا مقبولا وجود المناسبة والجهة الجامعة بين المعطوف والمعطوف عليه مفردا أو جملة، لأن (معظم أبواب الفصل والوصل مبني على الجامع).عاش فن الفصل والوصل في وجدان الناطق العربي، الذي احتاج أن يربط بين معنى ومعنى برابط، أو يقطع معنى عن معنى بقاطع، وهو في فصله ووصله يهدف إلى تحقيق غاية جمالية يسمو إليها، لأنه يحرص على أداء فكرته في وضوح لا لبس فيه لتصل إلى المخاطب في جمال وجلاء.والنصوص تشهد أن الحس العربي والمصفّى كان يتوقع الوصل حين لا يجد وصلاً، ويبحث عن الفصل حين يفتقده، وكان يفاضل بين رابط ورابط حتى يستقيم الشكل مع المضمون، وقصة أبي بكر الذي رفض من الأعرابي قوله (لا عافاك اللّ) وطالبه بأن يقول (لا وعافاك اللّ) تدل على ذلك.r والقرآن الكريم الذي خاطب هذه الطبيعة العربية كان يفصل بين المعاني ويربط بينها، وكان يلون العبارة مزاوجاً بين فصل ووصل ثقة بفهم المخاطب أو مراعاة منه لمقتضى الحال. ولم يتقيد في فصله بطرح الواو، بل استخدم معه أدوات أخرى، كما لم يقتصر في وصله على الواو أو على حروف العطف بل استخدم معها أدوات الربط الأخرى حسبما اقتضت الحاجة.وهو في كل هذا يرمي إلى إبراز جمال المعنى لتحقيق كمال الفائدة، فحين يصف مشاهد الجنة أو النار، أو يصور الثواب أو العقاب أو يتحدث عن الأخبار أو الفُجّار أو غير ذلك من معان، لا يعرضها عرضاً

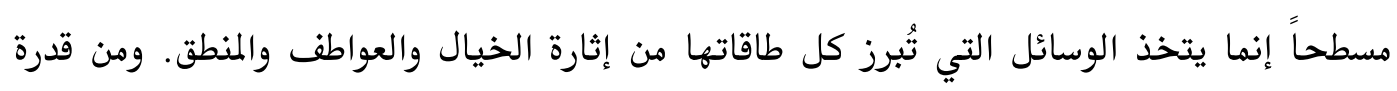

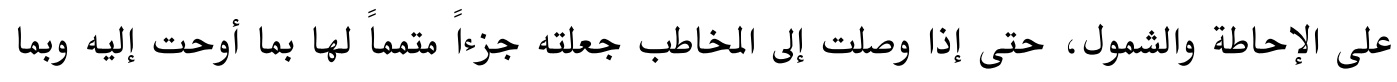
أثرت فيه ، وبما صورت له ، وبما أمتعته وأفادته.

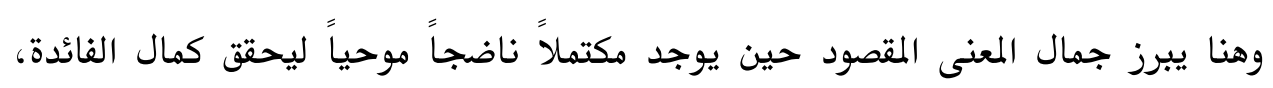

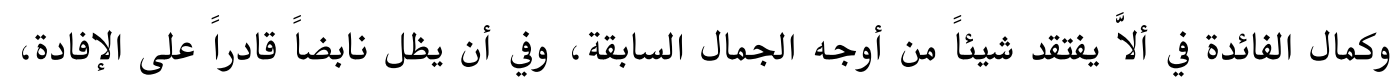
مؤدياً إلى معانٍ ومعانٍ تتواجد بوجوده. وتنبعث من إيحائه، ثم تترابط - هذه المعاني الجزئية VVT/10، اتاج العروس عن جواهر القاموس، محب الدين فيض السيد محمد الحسين الزبيدي،

'A Jamiy, Jurnal Bahasa dan Sastra Arab Volume 06, No. 2, September 2017 
لتصور المعنى الكلي، لتصور الحكمة المنشودة، أو الفكرة المقصودة أو الجوهر المطلوب.والوصل

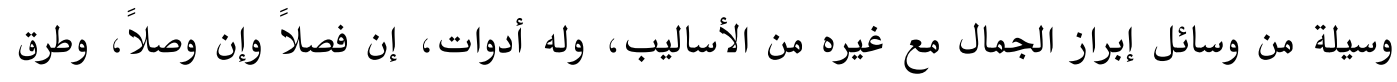
لأداء وظيفته، فقد يفصل القرآن الكريم بين معنيين أو يربط بينهما، متخذاً الإيضاح وسيلة لإبراز

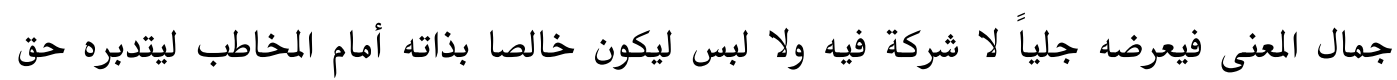
التدبر، أو يتخذ الإيجاز وسيلة في عرضه كيلا يتشتت الذهن في استيعاب المعنى، أو يحاول تثبيته لئه

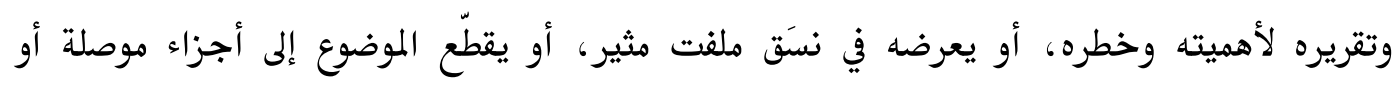
يعرضه بأشكال متعددة أو يقف أمام الهيئة المنفصلة أو الهيئة المتصلة ليرصد حركتها ويصور أبعادها أو يناسب بين الإيقاع الصوتي والإيقاع الدلالي أو غير ذلك. r. احرف واو الوصل و معانيها في الجزء الثلاثين

وتمثل سياقات الوصل في الخطاب العلوي ملمحا أسلوبيا بارزا، لكثرة ورودها فيه، إذ لا

تكاد تخلو منها خطبة من خطبه، وقد تمثل حضورها في نمطين، هما : النمط الأول : القصد إلى إشراك الجملتين في الحكم الإعرابي، وذلك عندما يكون للجملة الأولى محل من الإعراب فضلا عما بينهما من المناسبة في المعنى، وهو بذلك يكون كعطف المفرد على المفرد. ومما جاء على هذا النمط قوله : (ثم أسكن سبجانه آدم دارا أرغد فيها عيشه ، وآمن فيها محلته). فجملة (أرغد فيها عيشه) ذات موضوع من الإعراب لوقوعها صفه لـ (دارا) وقد عطفت عليه جملة (وآمن فيها محلته) لقصد التشريك في ذلك الحكم الإعرابي فضلا عما لها من تناسب، إذ استطاع العطف بين هذه الجمل أن يرسم لنا صفات تلك الدار (الجنة)، فقد وصفها بأنها دار ذات أمن وأمان وعيش رغيد، لا يصيبه فيها خوف أو حزن ما دام فيها. الآيات سورة النباء رقم

19,11

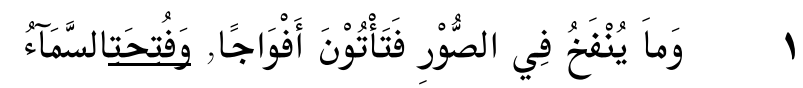
فَكَانَتْ أََْوَابًا

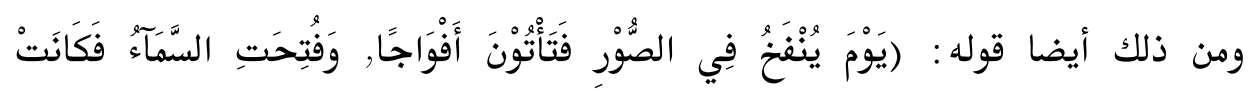

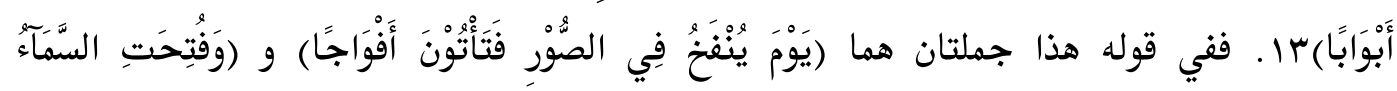

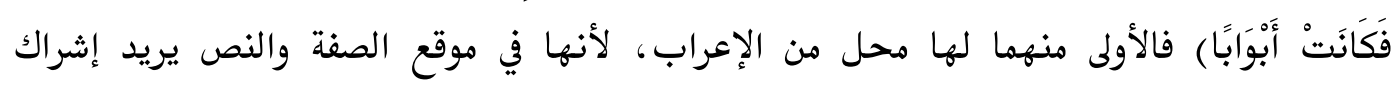
الجملة الثانية لها في هذا الحكم الإعراب، لما بينهما من تناسب في المعنى، إذ أن المخبر عنه في

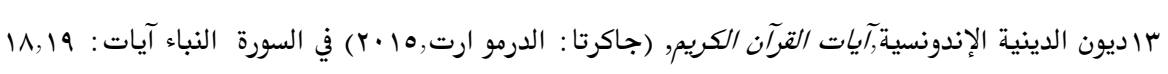

\section{'A Jamiy, Jurnal Bahasa dan Sastra Arab} Volume 06, No. 2, September 2017 
فيجملتين واحد، فكان - (الواو) فضل قوة الجمع بينهما مفيدا دلالة المدح والتعظيم لهم، فجاء العطف هنا عاملا مساعدا في بيان المعنى النفسي الذي ساد على هذه الجمل.

\begin{tabular}{|c|c|}
\hline الآيات & سورة الانشقاق \\
\hline $1, r, r$ & 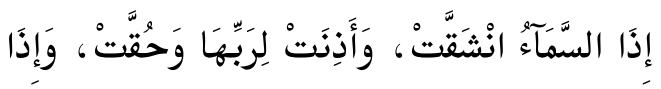 \\
\hline & الَْرْضُ مُدَّتَْ \\
\hline
\end{tabular}

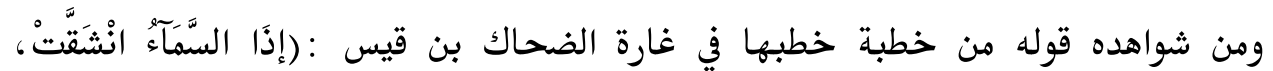

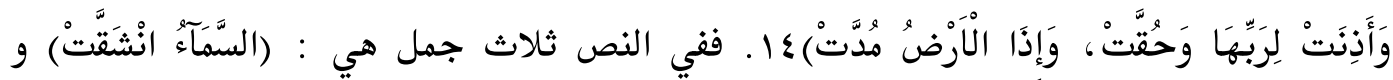

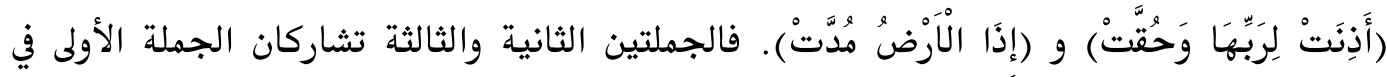
حكمها الإعرابي ومعناها، إذ المقصود من قوله هذا الإخبار عن المبتدأ (الضمير) المتمثل في قوله :(أصبحت) فهذه الأمور الثلاثة فوصل بينها، كما أن غرض الإمام لا يتحقق إلا بالوصل إتماما لمعنى المبالغة في توبيخهم ودمهم ( لـعدم وثوقه بأقوالهم لكثرة خلفهم ومواعيدهم الباطلة بالنهوض معه). فاستطاع العطف هنا أن يسترفد كل المعاني التي وردت في النص.

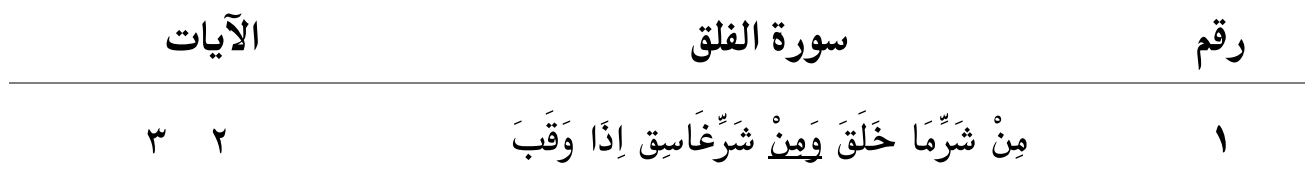

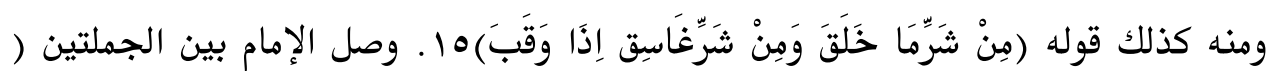
شَرِّمَا خَلَقَ ) و ( إِذَا وَقَبَ) لا شتراكهما في الحكم الإعرابي والمعنى. فكلتاهما في محل رفع خبر لاسم إن (خَلَقَ ) مذبها بادبارها واعلامها بالوداع (إلى تقضي الأحوال الحاضرة بالنسبة إلى كل شخص من الناس من صحة شباب وجاه ومال وكل ما يكون سببا لصلاح حال الإنسان). وإشراكهما في المعنى كل ذلك في معرض الدم لها، كما حقق الوصل . (الواو) دلالة قوة الجمع بينهما، لأن المخبر عنه واحد هو (خَلَقَ ). النمط الثاني : اتفاق الجملتين خبرا وإنشاء مع المناسبة في المعنى، ويتحقق ذلك حين تتفق الجملتان خبرا أو إنشاء لفظا ومعنى أو معنى مع وجود المناسبة بينهما في المعنى. فالوصل هنا

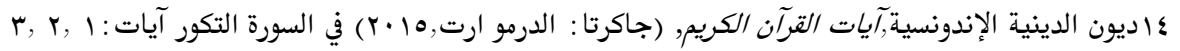

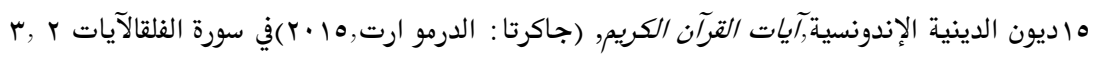

\section{'A Jamiy, Jurnal Bahasa dan Sastra Arab Volume 06, No. 2, September 2017}


إنما يتم إذن لاتفاق الجملتين في الأسلوب والمعنى وسأتي هذا الموضوع على خلاف موضوع كمال

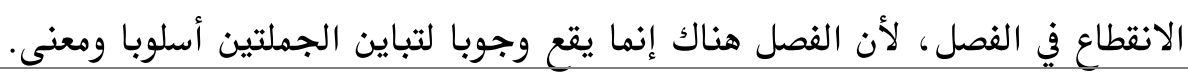

\begin{tabular}{|c|c|c|}
\hline الآيات & سورة الأعلى & رقم \\
\hline$\varepsilon, r, r$ & 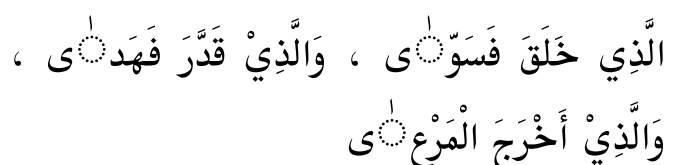 & 1 \\
\hline
\end{tabular}

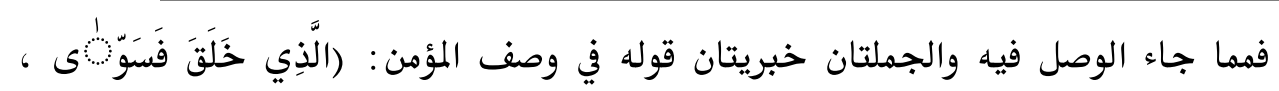

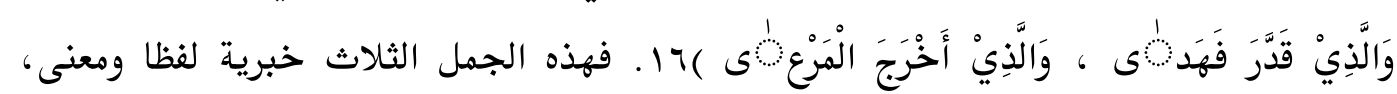

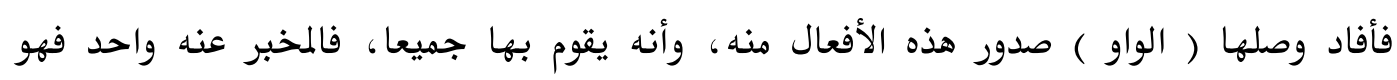

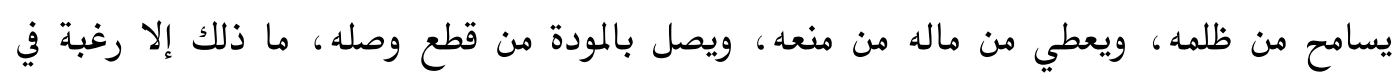

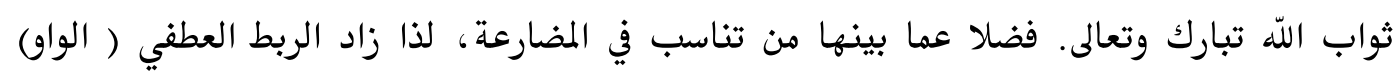
الدلالة قوة مظهورا معبرا في المستوى العميق عن دلالة المدح والتعظيم له.

\begin{tabular}{|c|c|c|}
\hline الآيات & سورة الانفطار & رقم \\
\hline$\varepsilon, r, r, l$ & 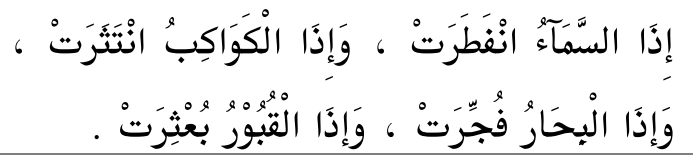 & 1 \\
\hline
\end{tabular}

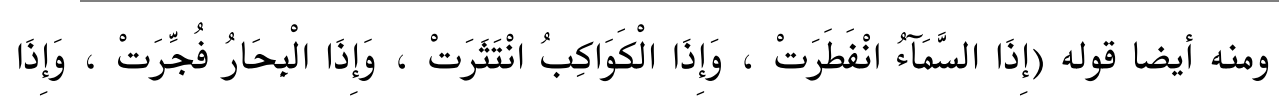

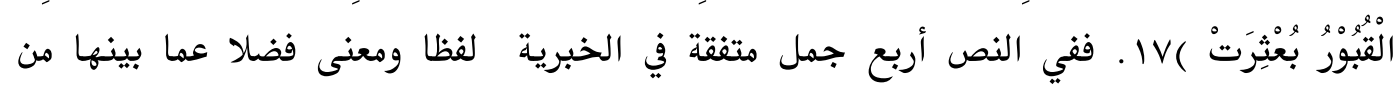

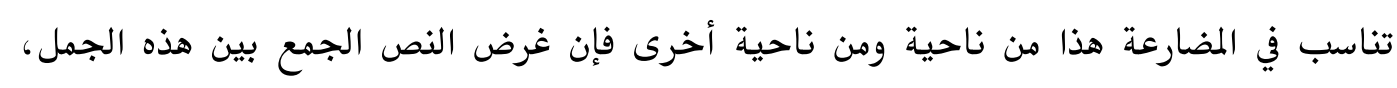

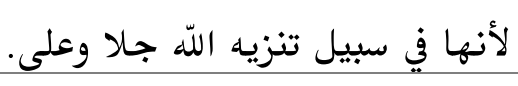

\begin{tabular}{|c|c|c|}
\hline الآيات & سورة التكوير & رقم \\
\hline $11,1 V, 17$ & تَنَفَّنَ & 1 \\
\hline
\end{tabular}

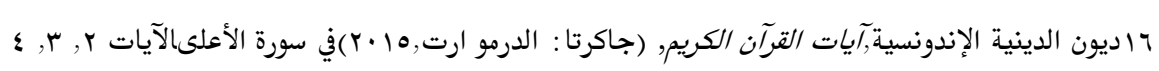

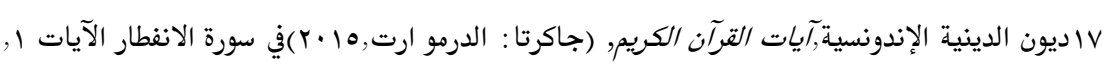

\section{'A Jamiy, Jurnal Bahasa dan Sastra Arab Volume 06, No. 2, September 2017}




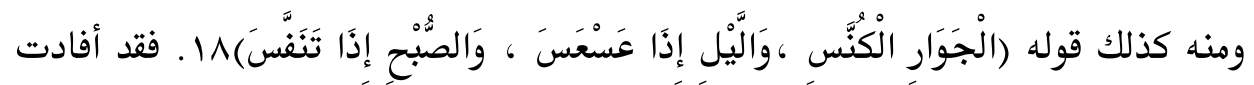

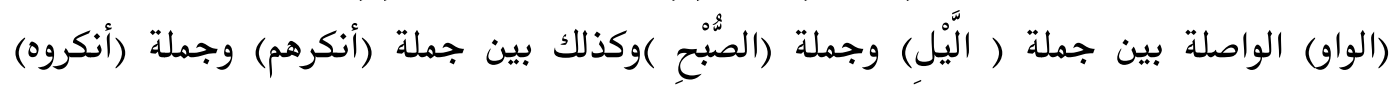

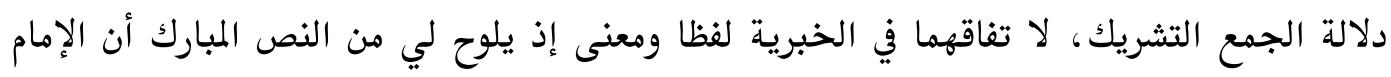

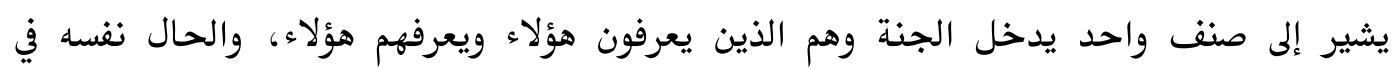
الصنف الذي يدخل النار.

\begin{tabular}{|c|c|c|c|}
\hline الآيات & & سورةَ نصُْ & رقم \\
\hline $1, r$ & وَرَايَيْتَ النَّاسَ & 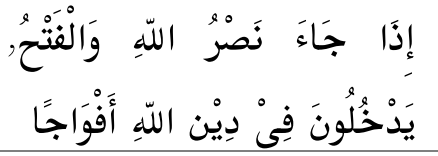 & 1 \\
\hline
\end{tabular}

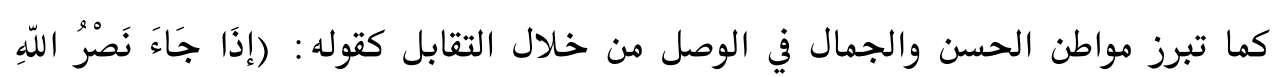

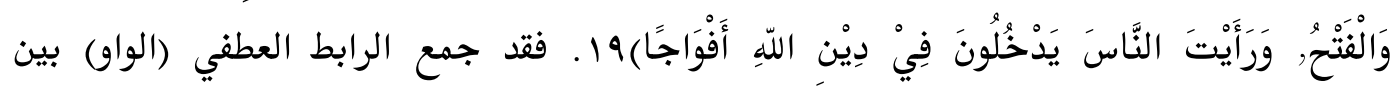

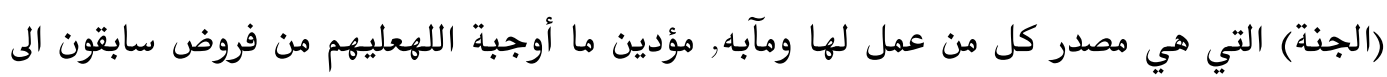

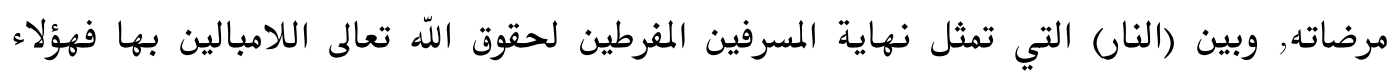

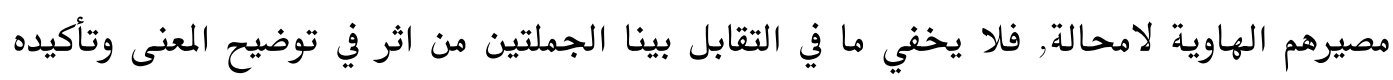
في نفوس المخاطبين.ومن مواطن التي يحسن الوصل فيها ب(الواو) ما جاء فيها اللفظ متباينا

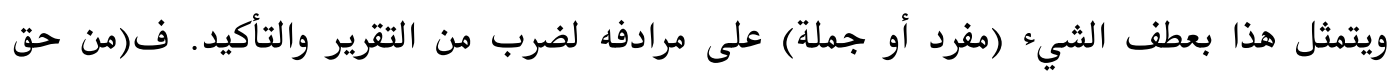

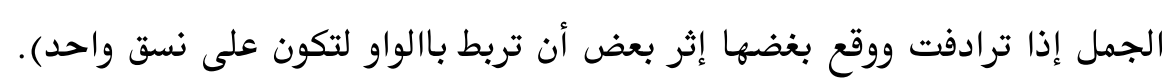

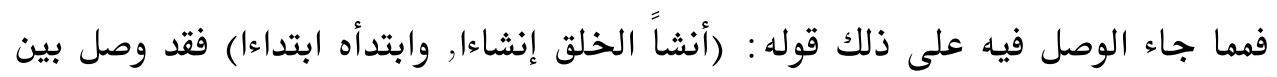
الجملتين لما بينهما من الاتفاق في الخبرية مع وجود المناسبة المتمثلة في تصوير قدره الله تبارك ولثك

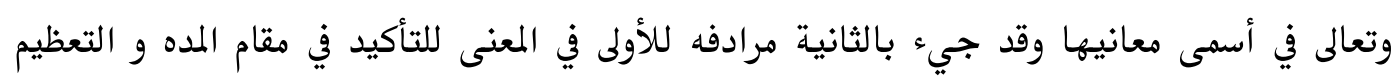

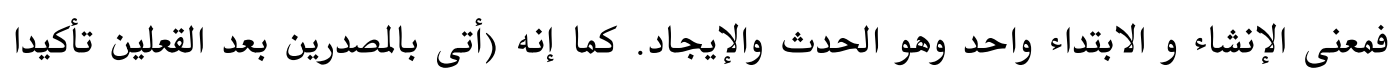
لمنسبة الفعلين إلى اللّ تعالى).

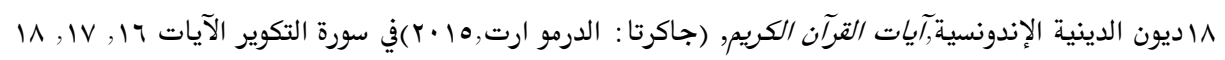

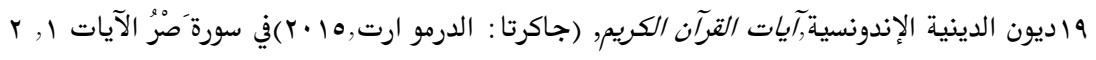

\section{'A Jamiy, Jurnal Bahasa dan Sastra Arab Volume 06, No. 2, September 2017}




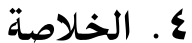

الوصل يعني عند علماء المعاني عطـف جملـة علسى اخـرى بـالوو فتـط مسن دون سـائر

حروف العطف الاحرى,الوصل هو جمع وربط بين جملتين بـ(الواو) خاصة لصلة بينهما في الصورة والمعنى اولدفع اللبس . و في الجزء الثلاثين جدا احرف واو الوصل مائة ثلاثـة و ثمـانين رمنهـا في السورة النباء جدا عشرة احرف واو وصـل , في السـورةالنازعات جـدا خمسـة احسرف واو وصـل و غيرها .

$$
\text { المراجع }
$$

$$
\begin{aligned}
& \text { ليكسي موليونج، طرق البحث النوعيّ، (باندنج : رامج روصدا كاريا،...ب) }
\end{aligned}
$$

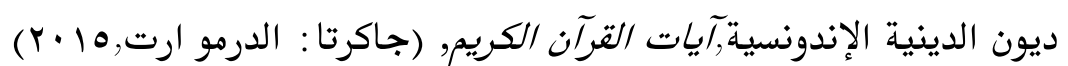

شمس الدين بن الجزري، مذجد المقرئين ومرشد الطالبين ،جزء الأول، (بيروت: دار الكتب العلمية،

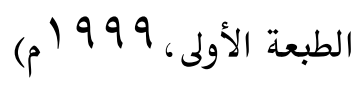

علي الجارم ومصطفى أمين ، البلاغة الواضحة البيان المعيني البديع (قاهرة: دار المعارف ، ؟ 9 | )

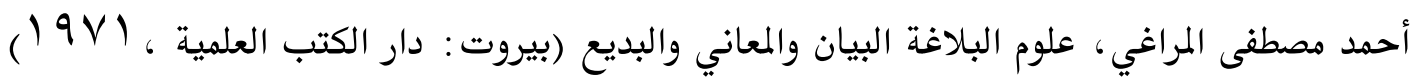

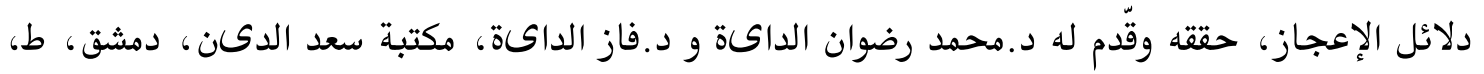

$$
\text { I } 9 \wedge V: Y T H \text {. }
$$

تاج العروس عن جواهر القاموس، محب الدين فيض السيد محمد الحسين الزبيدي، مVT/10

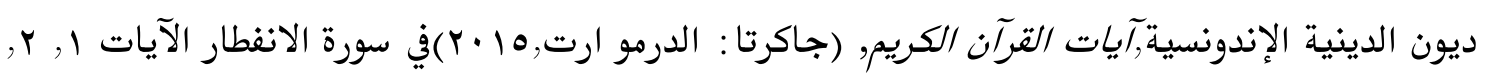
$\varepsilon, r$

\section{'A Jamiy, Jurnal Bahasa dan Sastra Arab}

